\title{
Model study of the impacts of future climate change on the hydrology of Ganges-Brahmaputra-Meghna basin
}

\author{
M. Masood ${ }^{1,2}$, P. J.-F. Yeh ${ }^{3}$, N. Hanasaki ${ }^{4}$, and K. Takeuchi ${ }^{1}$ \\ ${ }^{1}$ International Centre for Water Hazard and Risk Management (ICHARM), PWRI, Tsukuba, Japan \\ ${ }^{2}$ National Graduate Institute for Policy Studies (GRIPS), Tokyo, Japan \\ ${ }^{3}$ National University of Singapore, Singapore \\ ${ }^{4}$ National Institute for Environmental Studies, Tsukuba, Japan \\ Correspondence to: M. Masood (masood35bd@yahoo.com)
}

Received: 19 April 2014 - Published in Hydrol. Earth Syst. Sci. Discuss.: 2 June 2014

Revised: 28 December 2014 - Accepted: 7 January 2015 - Published: 4 February 2015

\begin{abstract}
The intensity, duration, and geographic extent of floods in Bangladesh mostly depend on the combined influences of three river systems, the Ganges, Brahmaputra and Meghna (GBM). In addition, climate change is likely to have significant effects on the hydrology and water resources of the GBM basin and may ultimately lead to more serious floods in Bangladesh. However, the assessment of climate change impacts on the basin-scale hydrology by using wellcalibrated hydrologic modeling has seldom been conducted in the GBM basin due to the lack of observed data for calibration and validation. In this study, a macroscale hydrologic model $\mathrm{H} 08$ has been applied over the basin at a relatively fine grid resolution $(10 \mathrm{~km})$ by integrating the fine-resolution DEM (digital elevation model) data for accurate river networks delineation. The model has been calibrated via the analysis of model parameter sensitivity and validated based on long-term observed daily streamflow data. The impacts of climate change (considering a high-emissions path) on runoff, evapotranspiration, and soil moisture are assessed by using five CMIP5 (Coupled Model Intercomparison Project Phase 5) GCMs (global circulation models) through three time-slice experiments; the present-day (1979-2003), the near-future (2015-2039), and the far-future (2075-2099) periods. Results show that, by the end of 21 st century, (a) the entire GBM basin is projected to be warmed by $\sim 4.3^{\circ} \mathrm{C}$; (b) the changes of mean precipitation (runoff) are projected to be $+16.3 \%(+16.2 \%),+19.8 \%(+33.1 \%)$, and $+29.6 \%$ $(+39.7 \%)$ in the Brahmaputra, Ganges, and Meghna, respectively; and (c) evapotranspiration is projected to increase for the entire GBM (Brahmaputra: $+16.4 \%$, Ganges: $+13.6 \%$,
\end{abstract}

Meghna: $+12.9 \%$ ) due to increased net radiation as well as warmer temperature. Future changes of hydrologic variables are larger in the dry season (November-April) than in the wet season (May-October). Amongst the three basins, the Meghna shows the highest increase in runoff, indicating higher possibility of flood occurrence. The uncertainty due to the specification of key model parameters in model predictions is found to be low for estimated runoff, evapotranspiration and net radiation. However, the uncertainty in estimated soil moisture is rather large with the coefficient of variation ranging from 14.4 to $31 \%$ among the three basins.

\section{Introduction}

Bangladesh is situated in the active delta of three of the world's major rivers, the Ganges, Brahmaputra and Meghna. Due to its unique geographical location, the occurrence of water-induced disasters is a regular phenomenon. In addition, the anticipated change in climate is likely to lead to an intensification of the hydrological cycle and to have a major impact on the overall hydrology of these basins and ultimately lead to the increase in the frequency of water-induced disasters in Bangladesh. However, the intensity, duration and geographic extent of floods in Bangladesh mostly depend on the combined influences of these three river systems. Previous studies indicated that flood damages have become more severe and devastating when more than one flood peak in these three river basins coincide (Mirza, 2003; Chowdhury, 2000). 
The Ganges-Brahmaputra-Meghna (hereafter referred to as GBM) basin with a total area of about 1.7 million $\mathrm{km}^{2}$ (FAO-AQUASTAT, 2014; Islam et al., 2010) is shared by a number of countries (Fig. 1). The Brahmaputra River begins in the glaciers of the Himalayas and travels through China, Bhutan, and India before emptying into the Bay of Bengal in Bangladesh. It is snow-fed braided river and it remains a natural stream with no major hydraulic structures built along its reach. The Ganges River originates at the Gangotri glaciers in the Himalayas and it passes through Nepal, China and India and empties into the Bay of Bengal at Bangladesh. It is snowmelt-fed river and its natural flow is controlled by a number of dams constructed by the upstream countries. The Meghna River is a comparatively smaller, rain-fed, and relatively flashier river that runs through a mountainous region in India before entering Bangladesh. Major characteristics of the GBM Rivers are presented in Table 1. This river system is the world's third largest freshwater outlet to the oceans (Chowdhury and Ward, 2004). During extreme floods, over $138700 \mathrm{~m}^{3} \mathrm{~s}^{-1}$ of water flows into the Bay of Bengal through a single outlet, which is the world largest intensity, even exceeding that of the Amazon discharge by about 1.5 times (FAO-AQUASTAT, 2014). The GBM basin is unique in the world in terms of diversified climate. For example, the Ganges River basin is characterized by low precipitation $\left(760-1020 \mathrm{~mm} \mathrm{year}^{-1}\right)$ in the northwestern upper region and high precipitation (1520-2540 $\mathrm{mm}_{\text {year }}{ }^{-1}$ ) along the coastal areas. High precipitation zones and dry rain shadow areas are located in the Brahmaputra River basin, whereas the world's highest precipitation (11 $871 \mathrm{~mm}$ year $^{-1}$ at Mawsynram, Meghalaya state, India) area is situated in the Meghna River basin (FAO-AQUASTAT, 2014).

Several studies have focused on the rainfall and discharge relationships in the GBM basin by (1) identifying and linking the correlation between basin discharge and the El NiñoSouthern Oscillation (ENSO) and sea surface temperature (SST) (Chowdhury and Ward, 2004; Mirza et al., 1998; Nishat and Faisal, 2000), (2) analyzing available observed or reanalysis data (Chowdhury and Ward, 2004, 2007; Mirza et al., 1998; Kamal-Heikman et al., 2007), and (3) evaluating historical data of flood events (Mirza, 2003; Islam et al., 2010). Various statistical approaches were used in the above studies instead of using hydrologic model simulations. In recent years, a number of global-scale hydrologic model studies (Haddeland et al., 2011, 2012; Pokhrel et al., 2012) have been reported. Although their modeling domains include the GBM basin, these global-scale simulations are not fully reliable due to the lack of model calibration at both the global and basin scales.

Few studies have been conducted to investigate the impact of climate change on the hydrology and water resources of the GBM basin (Immerzeel, 2008; Kamal et al., 2013; Biemans et al., 2013; Gain et al., 2011; Ghosh and Dutta, 2012). In most of these studies, future streamflow is projected on the basis of linear regression between rainfall and streamflow derived from historical data (Immerzeel, 2008; Chowdhury and Ward, 2004; Mirza et al., 2003). Immerzeel (2008) used the multiple regression technique to predict streamflow at the Bahadurabad station (the outlet of Brahmaputra Basin) under future temperature and precipitation conditions based on a statistically downscaled GCM (global circulation model) output. However, since most hydrologic processes are nonlinear, they cannot be predicted accurately by extrapolating empirically derived regression equations to the future projections. The alternative for the assessment of climate change impacts on basin-scale hydrology is via well-calibrated hydrologic modeling, but this has rarely been conducted for the GBM basin due to the lack of observed data for model calibration and validation. Ghosh and Dutta (2012) applied a macroscale distributed hydrologic model to study the change of future flood characteristics at the Brahmaputra Basin, but their study domain is only focused on the regions inside India. Gain et al. (2011) estimated future trends of the low and high flows in the lower Brahmaputra Basin using outputs from a global hydrologic model (grid resolution: $0.5^{\circ}$ ) forced by multiple GCM outputs. Instead of model calibration, the simulated future streamflow is weighted against observations to assess the climate change impacts.

In this study, a hydrologic model simulation is conducted in which the calibration and validation is based on a rarely obtained long-term (1980-2001) observed daily streamflow data set in the GBM basin provided by the Bangladesh Water Development Board (BWDB). Relative to previous GBM basin studies, it is believed that the availability of this unique long-term streamflow data can lead to more precise estimation of model parameters and hence more accurate hydrological simulations and more reliable future projection of the hydrology over the GBM basin.

The objective of this study is to (1) setup a hydrologic model for the GBM basin and calibrate and validate the model with the long-term observed daily streamflow data, and (2) to study the impact of future climate changes on the basin-scale hydrology. A global hydrologic model H08 (Hanasaki et al., 2008, 2014) is applied regionally over the GBM basin at a relatively fine grid resolution $(10 \mathrm{~km})$ by integrating the fine-resolution $(\sim 0.5 \mathrm{~km})$ DEM (digital elevation model) data for the accurate river networks delineation. The hourly atmospheric forcing data from the Water and Global Change (WATCH) model-intercomparison project (Weedon et al., 2011) (hereafter referred to as WFD, i.e., WATCH forcing data set) are used for the historical simulations. WFD is considered as one of the best available global climate forcing data sets to provide accurate representation of meteorological events, synoptic activity, seasonal cycles and climate trends (Weedon et al., 2011). The studies by Lucas-Picher et al. (2011) and Siderius et al. (2013) found that for southern Asia and the Ganges, respectively, the WFD rainfall is consistent with the APHRODITE (Yatagai et al., 2012), a gridded $\left(0.25^{\circ}\right)$ rainfall product for the southern Asia region developed based on a large number of rain gauge 
Table 1. Major characteristics of the Ganges, Brahmaputra and Meghna river basins.

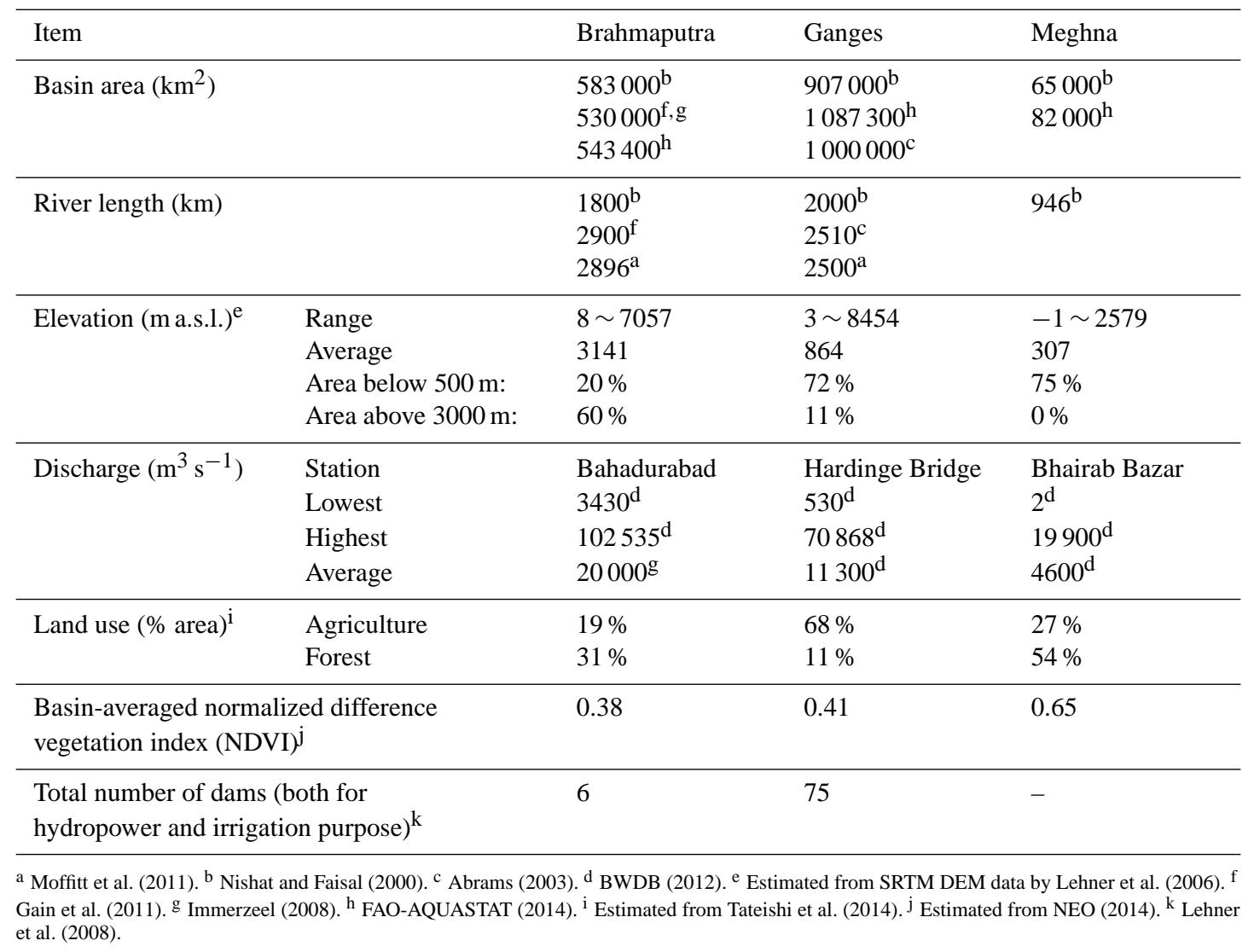

data. For future simulations, the H08 model is forced by climate model output under the high-emissions scenario (RCP 8.5 - representative concentration pathway) from five different coupled atmosphere-ocean GCMs, all of which participate in the Coupled Model Intercomparison Project Phase 5 (CMIP5) (Taylor et al., 2012). In order to be consistent with the historical data, for each basin the monthly correction factor (i.e., the ratio between the monthly precipitation of the WFD data and that of the GCM data for each month) is applied to the GCM's future precipitation outputs. Three time-slice experiments are performed for the presentday (1979-2003), the near-future (2015-2039), and the farfuture (2075-2099) periods.

Our present modeling study makes advances over previous similar studies in three aspects. First, the H08 model has been demonstrated as a suitable tool for large-scale hydrologic modeling (Hanasaki et al., 2008) and, in this study, it is first calibrated via analyzing model parameter sensitivity in the GBM basin before being validated against the observed long-term daily streamflow data set. Second, the uncertainty due to the determination of model parameters in hydrologic simulations, which is seldom considered in previous studies, is analyzed intensively in this study. Third, three large GBM basins and their spatial variability are studied, respectively, in this study via an integrated model framework which benefits the analysis of the combined influences of the three rivers on the large-scale floods and droughts in Bangladesh, as extensively reported in literature (Chowdhury, 2000; Mirza, 2003). Finally, the impacts of climate change not only on streamflow, but also on other hydro-meteorological variables, including evapotranspiration, soil moisture and net radiation, are also assessed in this study, unlike in most previous studies where the climate change impact on streamflow is often the only focus.

The paper is organized into five sections as follows. A brief description of the data and hydrologic model used is presented in Sect. 2. Section 3 presents the model setup as well as the results from the model parameter sensitivity analysis. Results and discussion are presented in Sect. 4, and important conclusions of this study are summarized in Sect. 5.

\section{Data and tools}

Basic information and characteristics (type, source, resolution and periods of data) of input data used in this study are summarized in Table 2. 


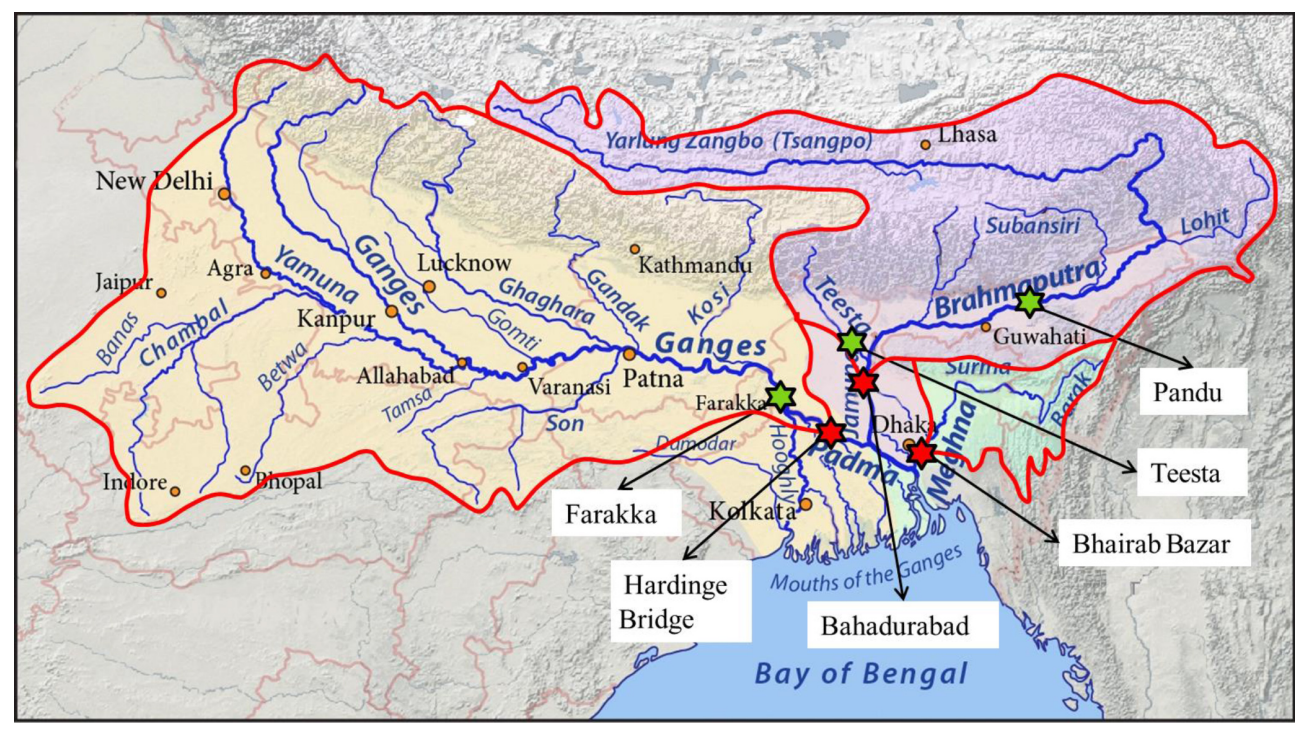

Figure 1. The boundary of the Ganges-Brahmaputra-Meghna (GBM) basin (thick red line), the three outlets (red star): Hardinge Bridge, Bahadurabad and Bhairab Bazar for the Ganges, Brahmaputra and Meghna river basins, respectively. Green stars indicate the locations of three additional upstream stations: Farakka, Pandu and Teesta (modified from Pfly, 2011).

\subsection{Meteorological forcing data sets}

The WFD (Weedon et al., 2011) is used to drive the H08 model for the historical simulation. The WFD variables, including rainfall, snowfall, surface pressure, air temperature, specific humidity, wind speed, long-wave downward radiation, and shortwave downward radiation were taken from the ERA-40 reanalysis product of the European Centre for Medium Range Weather Forecasting (ECMWF). The ERA reanalysis data with the $1^{\circ}$ resolution were interpolated into the $0.5^{\circ}$ resolution on the Climate Research Unit of the University of East Anglia (CRU) land mask, adjusted for elevation changes where needed and bias-corrected using monthly observations. For detailed information on the WFD, see Weedon et al. $(2011,2010)$. The albedo values are based on the monthly albedo data form the Second Global Soil Wetness Project (GSWP2).

\subsection{Hydrologic data}

Observed river water level (daily) and discharge (weekly) data from 1980 to 2012 for the hydrological stations located inside the Bangladesh (the outlets of three basins shown in Fig. 1, i.e., the Ganges Basin at Hardinge Bridge, the Brahmaputra Basin at Bahadurabad, and the Meghna Basin at Bhairab Bazar) were provided by the Hydrology Division, Bangladesh Water Development Board (BWDB). River water levels were regularly measured 5 times a day (at 06:00, 09:00, 12:00, 15:00 and 18:00 local time) and discharges were measured weekly by the velocity-area method. Since the Brahmaputra River is highly braided, the discharge measurements at Bahadurabad were carried out on multiple chan- nels. In contrast, the Meghna River at Bhairab Bazar is seasonally tidal - after withdrawal of the monsoon the river near this station becomes tidal, and from December to May the river shows both a horizontal and a vertical tide (Chowdhury and Ward, 2004). Under this condition, during the dry season tidal discharge measurements were made at this station once per month. Daily discharges of Ganges and Brahmaputra rivers were calculated from the daily water level data by using the rating equations developed by the Institute of Water Modelling (IWM) (IWM, 2006). A rating equation for the Meghna River is not reported in literature. In this study an attempt was made to develop the rating equation for the Meghna Basin. Discharge (monthly) data of another three stations (Farakka, Pandu, Teesta) located upstream of these basins (Fig. 1) were collected from the Global Runoff Data Centre (GRDC) and were also useful for model validation purposes.

\subsection{Topographic data}

DEM data were collected from HydroSHEDS (Hydrological data and maps based on SHuttle Elevation Derivatives at multiple Scales) (HydroSHEDS, 2014). It offers a suite of georeferenced data sets (vector and raster), including stream networks, watershed boundaries, drainage directions, and ancillary data layers such as flow accumulations, distances and river topology information (Lehner et al., 2006). The HydroSHEDS data were derived from the elevation data of the Shuttle Radar Topography Mission (SRTM) at a $\sim 0.5 \mathrm{~km}$ resolution. Preliminary quality assessments indicate that the accuracy of HydroSHEDS significantly exceeds that of existing global watershed and river maps (Lehner et al., 2006). 


\subsection{GCM data}

Climate data from five CMIP5 climate models - MIROC5, MIROC-ESM, MRI-CGCM3, HadGEM2-ES (under the RCP 8.5) and MRI-AGCM3.2S (under the SRES A1B - Special Report on Emissions Scenarios) - are used in this study as the forcing data for future hydrological simulations (see Appendix B, Table B1). The climate data have been interpolated from their original climate model resolutions (ranging from $0.25 \times 0.25^{\circ}$ to $\left.2.8 \times 2.8^{\circ}\right)$ to $5^{\prime} \times 5^{\prime}(\sim 10 \mathrm{~km}-$ mesh) using linear interpolation (nearest four-point). In order to be consistent with the historical simulation forced by WFD, the precipitation forcing data in each GBM basin from each GCM are corrected by multiplying a monthly correction factor, which is equal to the ratio between the basinaveraged long-term mean precipitation from WFD and that from each GCM for all the months. Among these GCMs, MRI-AGCM3.2S (where the "S" refers to the "super-high resolution") provides higher-resolution $(20 \mathrm{~km})$ atmospheric forcing data which shows improvements in simulating heavy precipitation, global distribution of tropical cyclones, and the seasonal march of the east Asian summer monsoon (Mizuta et al., 2012). The MRI-AGCM3.2S forcing data set has been used in several recent climate change impact studies focused on southern Asia (Rahman et al., 2012; Endo et al., 2012; Kwak et al., 2012).

\subsection{Hydrologic model: H08}

H08 is a macroscale hydrological model developed by Hanasaki et al. (2008) which consists of six main modules: land surface hydrology, river routing, crop growth, reservoir operation, environmental flow requirement estimation, and anthropogenic water withdrawal. For this study, only two modules, the land surface hydrology and the river routing are used. The land surface hydrology module calculates the energy and water budgets above and beneath the land surface as forced by the high-temporal-resolution meteorological data.

The runoff scheme in H08 is based on the bucket model concept (Manabe, 1969) but differs from the original formulation in certain important aspects. Although runoff is generated only when the bucket is overfilled as in the original bucket model, H08 uses a "leaky bucket" formulation in which subsurface runoff occurs continually as a function of soil moisture. Soil moisture is expressed as a single-layer reservoir with the holding capacity of $15 \mathrm{~cm}$ for all the soil and vegetation types. When the reservoir is empty (full), soil moisture is at the wilting point (the field capacity). Evapotranspiration is expressed as a function of potential evapotranspiration and soil moisture (Eq. 2). Potential evapotranspiration and snowmelt are calculated from the surface energy balance (Hanasaki et al., 2008).

Potential evaporation $E_{\mathrm{P}}$ is expressed in this model as

$E_{\mathrm{P}}\left(T_{\mathrm{S}}\right)=\rho C_{D} U\left(q_{\mathrm{SAT}}\left(T_{\mathrm{S}}\right)-q_{a}\right)$, where $\rho$ is the density of air, $C_{D}$ is the bulk transfer coefficient, $U$ is the wind speed, $q_{\mathrm{SAT}}\left(T_{\mathrm{S}}\right)$ is the saturated specific humidity at surface temperature, and $q_{a}$ is the specific humidity. Evaporation from a surface $(E)$ is expressed as

$E=\beta E_{\mathrm{P}}\left(T_{\mathrm{S}}\right)$,

where

$\beta=\left\{\begin{array}{ll}1 & 0.75 W_{\mathrm{f}} \leq W \\ W / W_{\mathrm{f}} & W<0.75 W_{\mathrm{f}}\end{array}\right.$,

where $W$ is the soil water content and $W_{\mathrm{f}}$ is the soil water content at field capacity (fixed at $150 \mathrm{~kg} \mathrm{~m}^{-2}$ ).

Surface runoff $\left(Q_{\mathrm{s}}\right)$ is generated whenever the soil water content exceeds the field capacity:

$Q_{\mathrm{s}}=\left\{\begin{array}{ll}W-W_{\mathrm{f}} & W_{\mathrm{f}}<W \\ 0 & W \leq W_{\mathrm{f}}\end{array}\right.$.

Subsurface runoff $\left(Q_{\mathrm{sb}}\right)$ is incorporated to the model as

$Q_{\mathrm{sb}}=\frac{W_{\mathrm{f}}}{\tau}\left(\frac{W}{W_{\mathrm{f}}}\right)^{\gamma}$,

where $\tau$ is a time constant and $\gamma$ is a parameter characterizing the degree of nonlinearity of $Q_{\text {sb }}$. These two parameters are calibrated in this study as described later in Sect. 3.1.

The river module is identical to the Total Runoff Integrating Pathways (TRIP) model (Oki and Sud, 1998). The module has a digital river map covering the whole globe at a spatial resolution of $1^{\circ}(\sim 111 \mathrm{~km})$. The land-sea mask is identical to the GSWP2 meteorological forcing input. Effective flow velocity and meandering ratio are set as the default values at $0.5 \mathrm{~m} \mathrm{~s}^{-1}$ and 1.5 , respectively. The module accumulates runoff generated by the land surface model and routes it downstream as streamflow. However, for this study a new digital river map of the GBM basin with the spatial resolution of $\sim 10 \mathrm{~km}$ is prepared. Effective flow velocity and meandering ratio have been calibrated, respectively, for the three basins.

\section{Methodology: model setup and simulation}

Figure 2 presents the methodology used in this study from model setup to the historical and future simulations. The H08 simulation with the $10 \mathrm{~km}\left(5^{\prime}\right)$ resolution is calibrated to find the optimal parameter sets by using the parametersampling simulation technique, and validated with observed daily streamflow data. The default river module of H08 uses the digital river map from TRIP (Oki and Sud, 1998) with the global resolution of $1^{\circ}(\sim 111 \mathrm{~km})$ which is too coarse for the regional simulation in this study, which has the $10 \mathrm{~km}$ resolution. Therefore, a new digital river map of the $10 \mathrm{~km}$ resolution is prepared for this purpose by integrating the finerresolution $(\sim 0.5 \mathrm{~km})$ DEM data. 


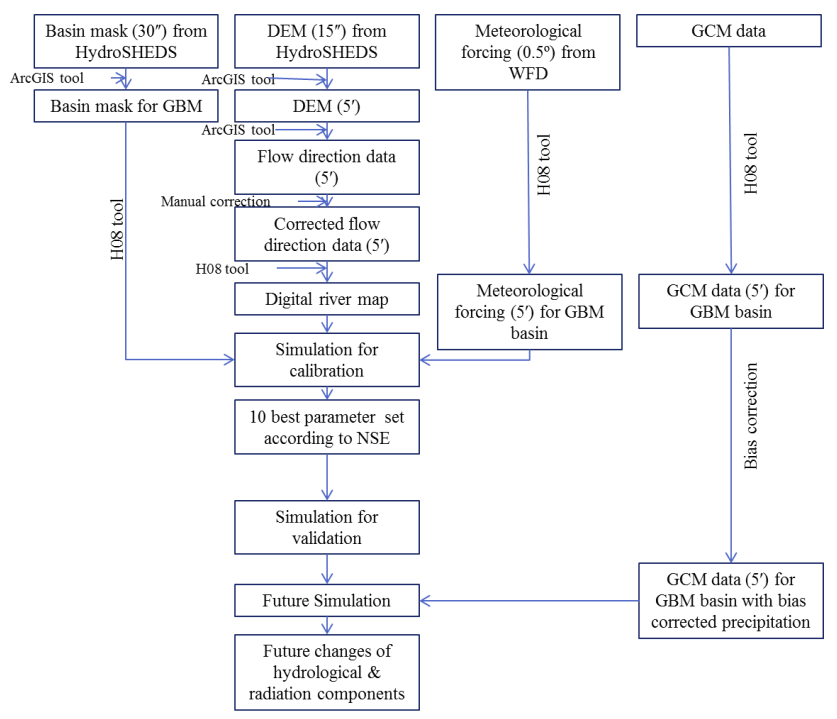

Figure 2. Flow chart of the methodology used in this study.

\subsection{Parameter sensitivity}

The parameter-sampling simulation is conducted to investigate the sensitivity of the H08 model parameters to simulation results. The most sensitive parameters in $\mathrm{H} 08$ include the root-zone depth $d(\mathrm{~m})$, the bulk transfer coefficient $C_{D}$ (-) controlling the potential evaporation (Eq. 1), and the parameters sensitive to subsurface flow, that is, $\tau$ (day) and $\gamma$ (-) (Eq. 5) (Hanasaki et al., 2014); hence, they are treated as calibration parameters in this study. The parameter $\tau$ is a time constant determining the daily maximum subsurface runoff. The parameter $\gamma$ is a shape parameter controlling the relationship between subsurface flow and soil moisture (Hanasaki et al., 2008). Their default parameter values in $\mathrm{H} 08$ are $1 \mathrm{~m}$ for $d, 0.003$ for $C_{D}, 100$ days for $\tau$, and 2 for $\gamma$. For each of these four parameters, five different values are selected from their feasible physical ranges. The parametersampling simulations of the $\mathrm{H} 08$ model were run by using all the combinations of four parameters, which consist of a total of $5^{4}(625)$ simulations conducted by using the same 11-year (1980 - 1990) atmospheric forcing data of WFD.

Figure 3 plots the 11-year long-term average seasonal cycles of simulated total runoff, surface runoff and subsurface runoff of the Brahmaputra Basin. Each of the five lines in each panel represents the average of $5^{3}(125)$ runs with one of the four calibration parameters fixed at a given value. As shown, the overall sensitivity of the selected model parameters to the flow partitioning is high. When $d$ is low, surface runoff is high (due to higher saturated fractional area) (Fig. 3b). As $d$ increases, subsurface runoff increases and surface runoff decreases (Fig. 3c and b). Due to these compensating effects, the effect of $d$ on the total runoff becomes more complex: from March to August higher $d$ causes lower total runoff, but the trend is reversed from August on for the
Brahmaputra Basin. Similar behaviors can be observed for the other two basins (figure not shown).

The parameter $C_{D}$ is the bulk transfer coefficient in the calculation of potential evaporation (Eq. 1); thus, its effect on runoff is relatively small (Fig. 3d-f). However, higher $C_{D}$ causes more evaporation and hence lower (both surface and subsurface) runoff (Eqs. 1, 2). The sensitivity of parameter $\gamma$ to runoff is also smaller than $d$ and $\tau$. As $\gamma$ increases, surface runoff increases and subsurface runoff decreases (Fig. 3h, i). The overall sensitivity of $\gamma$ to the total runoff becomes negligible due to the compensating effects (Fig. 3g).

As shown in Eq. (5) and Fig. 3k-1, the parameter $\tau$ has a critical impact on the surface and subsurface flow partitioning. A larger $\tau$ corresponds to larger surface runoff and hence smaller subsurface runoff (Fig. 3k-1), but it has relatively a small impact on total runoff (Fig. 3j).

These four calibration parameters have a combined influence on total runoff partitioning as well as on the simulations of other hydrologic variables. To summarize, (1) the sensitivity of $d$ on the total runoff is complex, i.e., the trend is reversed between the two halves of a year; (2) parameters $d$ and $\tau$ have a significant impact on flow partitioning whereas $C_{D}$ and $\gamma$ have less sensitivity to runoff simulation; and(3) the influence of $d$ and $\tau$ is reversed between surface and subsurface runoff: surface runoff increases as $d$ decreases and $\tau$ increases.

Figure $4 \mathrm{e}$ plots the uncertainty bands of the simulated discharges by using 10 optimal parameter combinations according to the Nash-Sutcliffe coefficient of efficiency (NSE) (Nash and Sutcliffe, 1970). It is observed that the spread of the uncertainty band is located mainly around the low flow period (dry season from November to March) over the Brahmaputra Basin (Fig. 4e). No surface runoff is generated in the dry season when the soil moisture is lower than the field capacity (Eq. 4 and Fig. 3b). It is noted from the 10 optimal parameter combinations that the optimal $\tau$ is 150 , $C_{D}$ is $0.001, d$ and $\gamma$ range from 3 to 5 and 1.0 to 2.5 , respectively. The spread of the uncertainty bands is mainly due to the variations of $d$ and $\gamma$. As $d$ increases, the subsurface runoff increases (Figs. 3c, 4e). On the other hand, in the case of the Ganges and Meghna basins the spread of uncertainty bands are observed through the entire period of a year (in low flow as well as in peak flow regimes). Among the 10 optimal parameter combinations for the Ganges (Meghna) it is found that parameter $C_{D}$ is $0.008(0.008), \tau$ is $150(50), d$ and $\gamma$ range from 4 to 5 (4 to 5 ) and 2.5 to 4 (1.5 to 2 ), respectively. In the dry period, when surface runoff is nearly zero, subsurface runoff increases as $d$ increases. A higher $C_{D}$ causes higher evaporation which influences runoff as well (Eq. 1). As discussed earlier, the influence of $d$ on the total runoff is complex, which results in the variation of simulated runoff throughout the year. The spread of the uncertainty bands is large in the peak flow period as the sensitivity of both surface and subsurface runoff is also large with respect to the value of $d$ (not shown). 

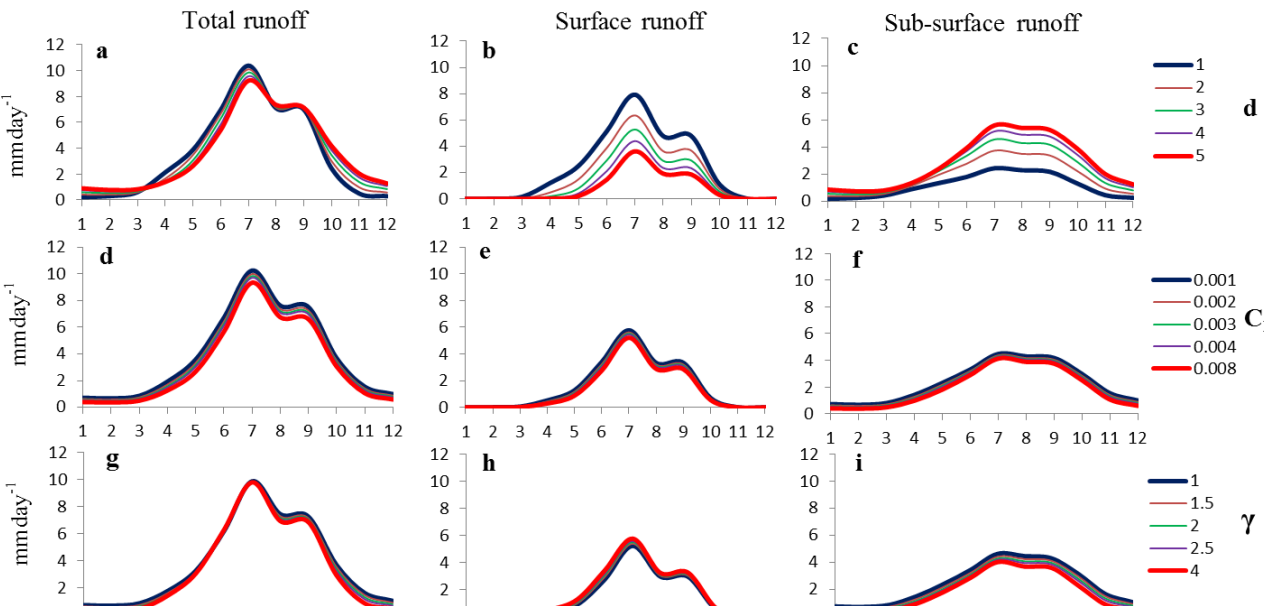

h
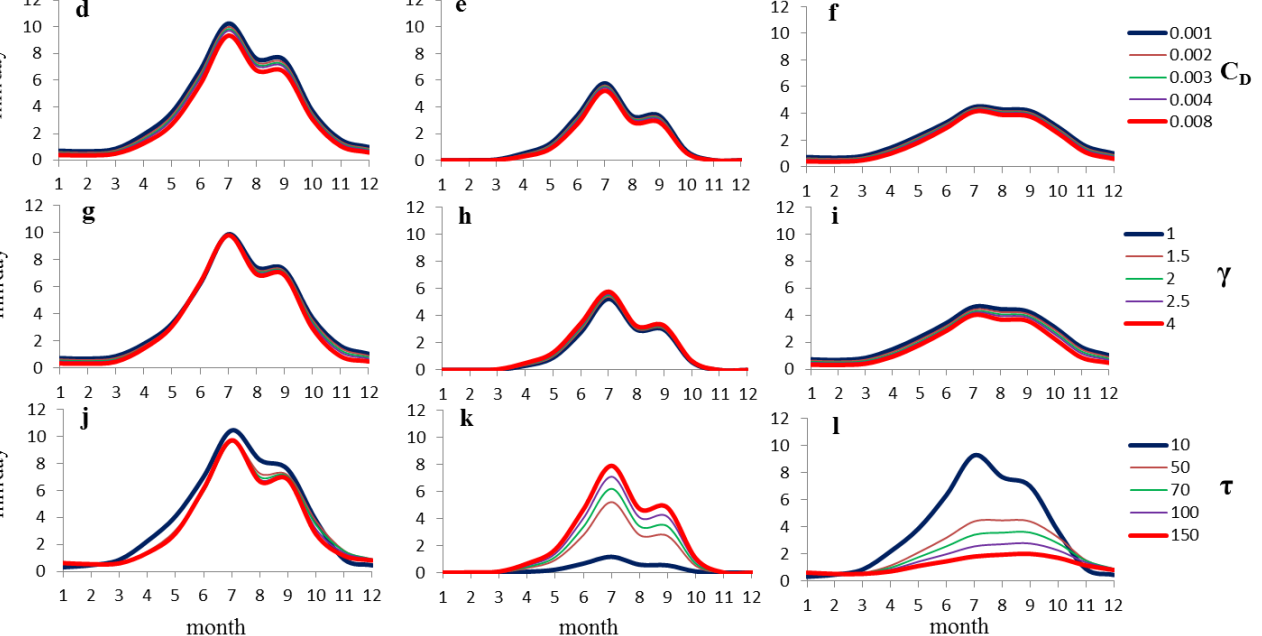

Figure 3. The 11-year (1980-1990) mean seasonal cycles of the simulated total runoff, surface runoff and subsurface runoff (mm day ${ }^{-1}$ ) in the Brahmaputra Basin. Each of the five lines in each panel represents the average of $5^{3}(125)$ runs with one of the four calibration parameters fixed at a given reasonable value.

\subsection{Calibration and validation}

The historical simulation from 1980 to 2001 is divided into two periods with the first half (1980-1990) as the calibration period and the second half (1991-2001) as validation. Basic information and characteristics (location, drainage area, and periods of available observed data) of the six validation stations in the GBM basin are summarized in Table 3. Model performance is evaluated by comparing observed and simulated daily streamflow by the NSE (Nash and Sutcliffe, 1970), the optimal objective function for assessing the overall fit of a hydrograph (Sevat and Dezetter, 1991). A series of sensitivity analysis of $\mathrm{H} 08$ parameters was conducted from which 10 sets of optimal parameters are determined by using the parameter-sampling simulation as discussed earlier; these parameter sets are used to quantify the uncertainty in both historical and future simulations in the following. Figure 4 plots the daily hydrograph comparisons at the outlets of the three river basins with the corresponding daily observations for both calibration and validation periods. The obtained NSE for the calibration (validation) period is 0.84 (0.78), 0.80 (0.77), and 0.84 (0.86), while the percent bias (PBIAS) is $0.28 \%(6.59 \%), 1.21 \%(2.23 \%)$ and $-0.96 \%$ $(3.15 \%)$ for the Brahmaputra, Ganges, and Meghna basins, respectively. For all basins, the relative root-mean-square error (RRMSE), the correlation coefficient (cc), and the coefficient of determination $\left(R^{2}\right)$ for the calibration (validation) period range from 0.32 to 0.60 ( 0.32 to 0.59$), 0.91$ to 0.93
( 0.89 to 0.94$)$ and 0.82 to 0.86 (0.79 to 0.88 ), respectively. These statistical indices (Table 4) suggest that the model performance is overall satisfactory. To further evaluate model performance at upstream stations, the monthly discharge data at three upstream stations (Farakka, Pandu, Teesta) collected from the GRDC are used to compare with model simulations, and the result shows that the mean seasonal cycle of simulated streamflow matches well with the corresponding GRDC observations in these three upstream stations (see Appendix A).

\section{Results and discussion}

The calibrated H08 model is applied to the simulations for the following three time-slice periods, the present (1979-2003), the near-future (2015-2039), and the far-future (2075-2099) period. For the present simulation, both WFD and GCM climate forcing data are used. For the future simulation, only GCM forcing data are used. Simulation results for the two future periods are then compared with the present period (1979-2003) simulation forced by a GCM to assess the effect of climate change on the hydrology and water resources of the GBM basin in terms of precipitation, air temperature, evapotranspiration, soil moisture and net radiation. The results are presented in the following. 

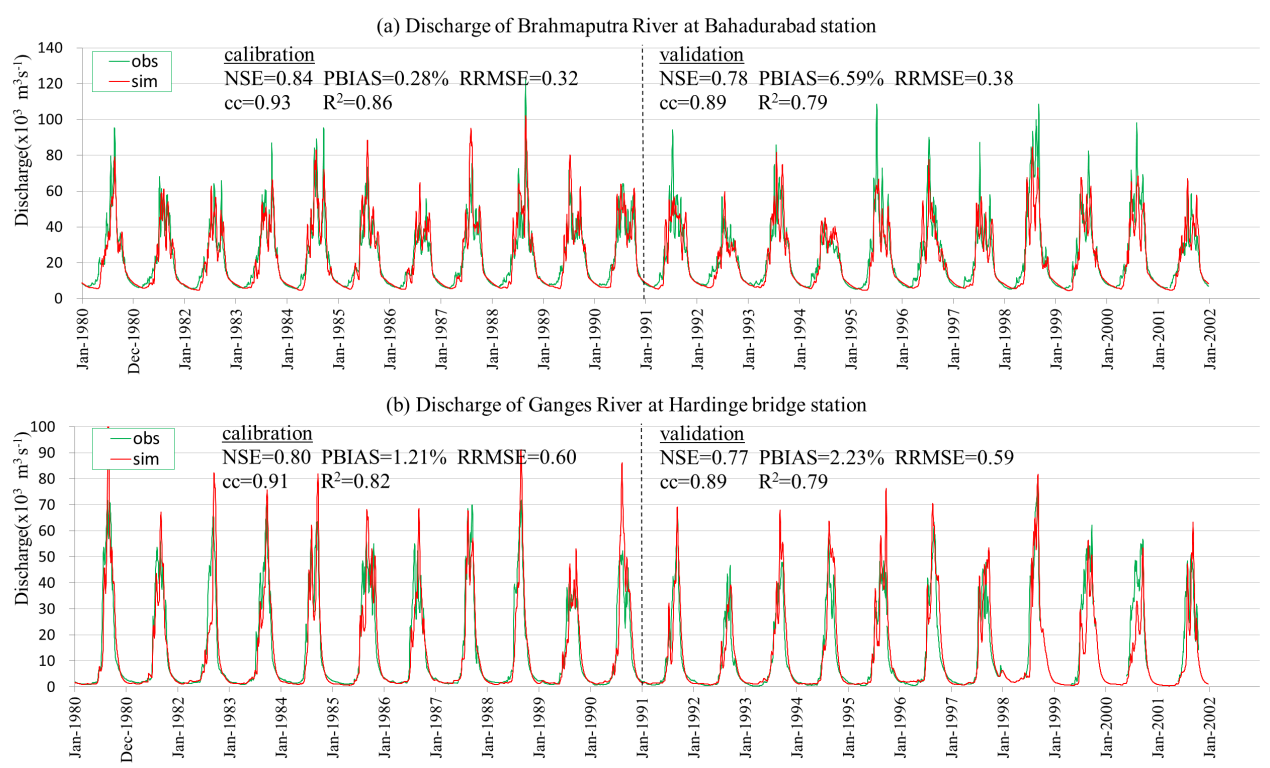

(c) Discharge of Meghna River at Bhairab bazar station

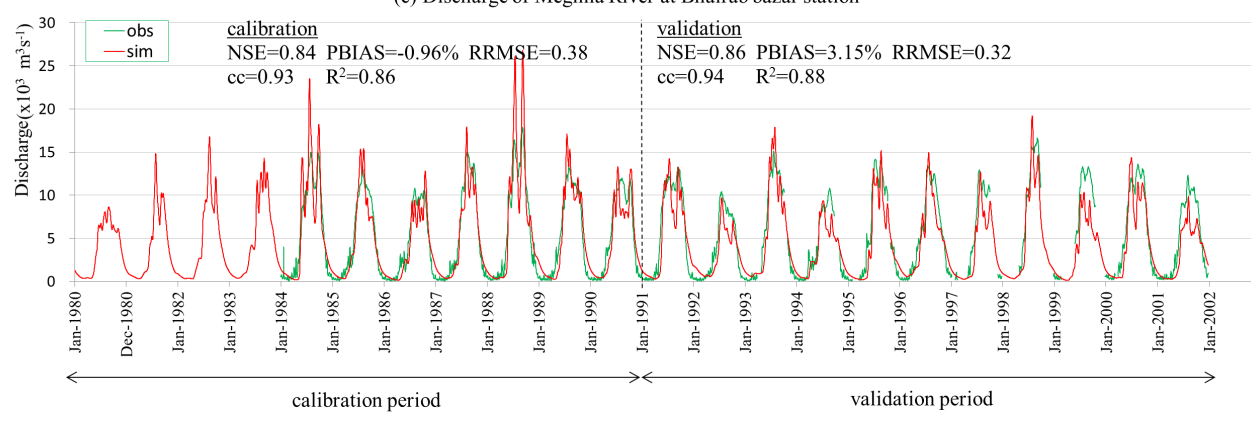

(d) Mean monthly discharge at outlet of three basin
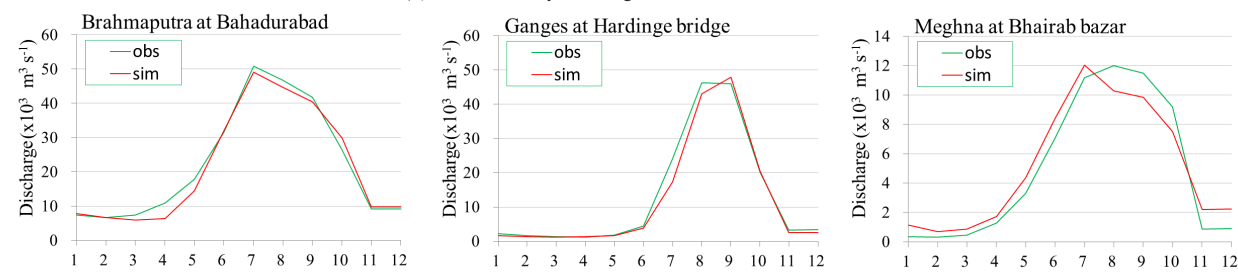

(e) Uncertainty band of simulated discharge with top 10 optimal parameter combination in a typical year (1985)

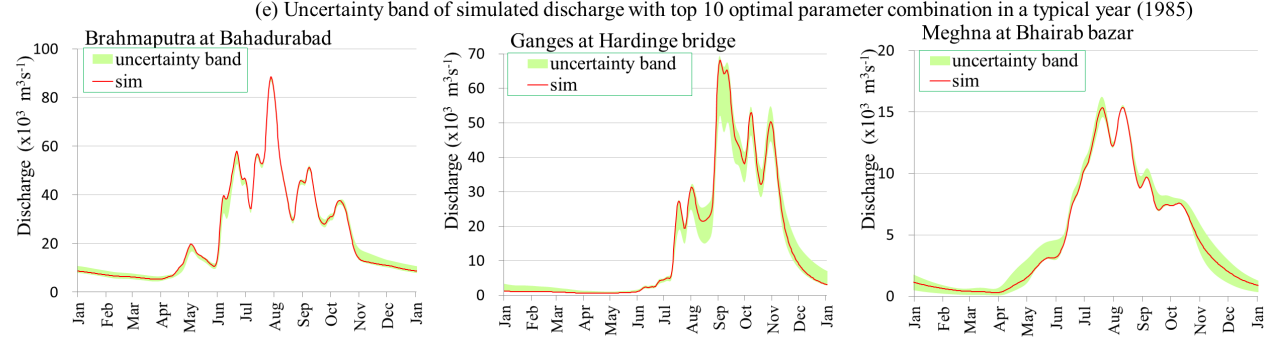

Figure 4. The simulated discharges (red line) using the WFD forcing data (both calibration and validation period) compared with observations (green line) at outlets of the (a) Brahmaputra, (b) Ganges, and (c) Meghna rivers, (d) mean monthly (1980-2001) simulated discharges compared with those of observations at outlets; (e) simulated discharges by using the 10 optimal parameter sets (red line) and the associated uncertainty bands (green shading) in a typical year (1985). NSE, PBIAS, RRMSE, cc and $R^{2}$ for both calibration and validation periods are noted at subplots (a), (b) and (c). 
Table 2. Basic input data used in this study.

\begin{tabular}{|c|c|c|c|c|c|}
\hline Type & Description & Source/reference(s) & $\begin{array}{l}\text { Original spatial resolu- } \\
\text { tion }\end{array}$ & Period & Remarks \\
\hline \multirow[t]{2}{*}{ Physical data } & $\begin{array}{l}\text { Digital elevation map } \\
\text { (DEM) }\end{array}$ & $\begin{array}{l}\text { HydroSHEDS }^{\mathrm{a}} \\
\text { (HydroSHEDS, 2014) }^{\text {(H) }}\end{array}$ & $15^{\prime \prime}(\sim 0.5 \mathrm{~km})$ & - & Global data \\
\hline & Basin mask & $\begin{array}{l}\text { HydroSHEDS }{ }^{\mathrm{a}} \\
\text { (HydroSHEDS, 2014) }\end{array}$ & $30^{\prime \prime}(\sim 1 \mathrm{~km})$ & - & \\
\hline \multirow[t]{2}{*}{ Meteorological data } & $\begin{array}{l}\text { Rainfall, snowfall, } \\
\text { surface pressure, air } \\
\text { temperature, specific } \\
\text { humidity, wind speed, } \\
\text { long-wave downward } \\
\text { radiation, shortwave } \\
\text { downward radiation }\end{array}$ & $\begin{array}{l}\mathrm{WFD}^{\mathrm{b}} \\
\text { (Weedon et al., 2010, } \\
\text { 2011) }\end{array}$ & $0.5^{\circ}$ & $1980-2001$ & $\begin{array}{l}5^{\prime}(\sim 10 \mathrm{~km} \text { mesh }) \text { data has been } \\
\text { prepared by linear interpolating } \\
\text { for this study. }\end{array}$ \\
\hline & albedo & GSWP2 $^{\mathrm{c}}$ & $1^{\circ}$ & 1980-1990 & $\begin{array}{l}\text { Mean monthly } 5^{\prime}(\sim 10 \mathrm{~km} \text { mesh }) \\
\text { data has been prepared for this } \\
\text { study. }\end{array}$ \\
\hline \multirow[t]{2}{*}{ Hydrologic data } & $\begin{array}{l}\text { Water level } \\
\text { discharge }\end{array}$ & $\begin{array}{l}\text { Bangladesh Water } \\
\text { Development Board } \\
\text { (BWDB) }\end{array}$ & Gauged & 1980-2012 & $\begin{array}{l}\text { Water level (daily), discharge } \\
\text { (weekly) data at outlets of three } \\
\text { basins, i.e., the Ganges Basin at } \\
\text { Hardinge Bridge, the Brahmapu- } \\
\text { tra Basin at Bahadurabad, and the } \\
\text { Meghna Basin at Bhairab Bazar } \\
\text { obtained from BWDB. }\end{array}$ \\
\hline & Discharge & $\begin{array}{l}\text { Global Runoff Data } \\
\text { Centre (GRDC) }\end{array}$ & Gauged & $\begin{array}{l}\text { 1949-1973 (Farakka), } \\
\text { 1975-1979 (Pandu), } \\
\text { 1969-1992 (Teesta) } \\
\text { with missing data }\end{array}$ & $\begin{array}{l}\text { Discharge (monthly) data at three } \\
\text { upstream stations, i.e., at Farakka } \\
\text { (Ganges), Pandu (Brahmaputra) } \\
\text { and Teesta (Brahmaputra). }\end{array}$ \\
\hline \multirow[t]{5}{*}{ GCM data } & $\begin{array}{l}\text { Rainfall, snowfall, } \\
\text { surface pressure, air } \\
\text { temperature, specific } \\
\text { humidity, wind speed, } \\
\text { long-wave downward } \\
\text { radiation, shortwave } \\
\text { downward radiation }\end{array}$ & MRI-AGCM $3.2 S^{\mathrm{d}}$ & $0.25^{\circ}(\sim 20 \mathrm{~km}-\mathrm{mesh})$ & $\begin{array}{l}1979-2003,2015- \\
2039,2075-2099\end{array}$ & $\begin{array}{l}\text { Bias of precipitation data set } \\
\text { has been corrected by multiply- } \\
\text { ing by the monthly correction } \\
\text { coefficient (ratio between basin- } \\
\text { averaged long-term monthly } \\
\text { mean precipitation from WFD } \\
\text { and that from each GCM) for } \\
\text { each GBM basins. }\end{array}$ \\
\hline & & MIROC5 & $1.41 \times 1.39^{\circ}$ & & \\
\hline & & MIROC-ESM & $2.81 \times 2.77^{\circ}$ & & \\
\hline & & MRI-CGCM3 & $1.125 \times 1.11^{\circ}$ & & \\
\hline & & HadGEM2-ES & $1.875 \times 1.25^{\circ}$ & & \\
\hline
\end{tabular}

Meteorological Research Institute-Atmospheric General Circulation Model.

Table 3. Basic information of the streamflow validation stations in the GBM basin.

\begin{tabular}{|c|c|c|c|c|c|c|}
\hline \multirow{2}{*}{$\begin{array}{l}\text { Basin name } \\
\text { Station name }\end{array}$} & \multicolumn{3}{|c|}{ Brahmaputra } & \multicolumn{2}{|c|}{ Ganges } & \multirow{2}{*}{$\begin{array}{l}\text { Meghna } \\
\text { Bhairab Bazar }\end{array}$} \\
\hline & Bahadurabad & Pandu & Teesta & Hardinge Bridge & Farakka & \\
\hline Latitude & $25.18^{\circ} \mathrm{N}$ & $26.13^{\circ} \mathrm{N}$ & $25.75^{\circ} \mathrm{N}$ & $24.08^{\circ} \mathrm{N}$ & $25^{\circ} \mathrm{N}$ & $25.75^{\circ} \mathrm{N}$ \\
\hline Longitude & $89.67^{\circ} \mathrm{E}$ & $91.7^{\circ} \mathrm{E}$ & $89.5^{\circ} \mathrm{E}$ & $89.03^{\circ} \mathrm{E}$ & $87.92^{\circ} \mathrm{E}$ & $89.5^{\circ} \mathrm{E}$ \\
\hline Drainage area $\left(\mathrm{km}^{2}\right)$ & 583000 & 405000 & 12358 & 907000 & 835000 & 65000 \\
\hline $\begin{array}{l}\text { Available observed } \\
\text { data period (with missing) }\end{array}$ & 1980-2001 & 1975-1979 & 1969-1992 & 1980-2001 & 1949-1973 & 1980-2001 \\
\hline
\end{tabular}

\subsection{Seasonal cycle}

Figure 5 plots the 22-year (1980-2001) mean seasonal cycles of the climatic (from WFD forcing) and hydrologic (from model simulations) quantities averaged over the three basins (the corresponding mean annual amounts of these variables are presented in Table 5). Also given in Fig. 5 is the box-and- whisker plot showing the range of variability for each month. The interannual variation of precipitation in the Brahmaputra and Meghna basins is high from May to September (Fig. 5a, c), whereas in the Ganges it is from June to October. However, the magnitude of precipitation differs substantially among the three basins. The Meghna Basin has a significantly higher precipitation than the other two basins 
Table 4. Statistical indices that measure the model performance in the three basins (GBM) during both calibration and validation periods.

\begin{tabular}{|c|c|c|c|c|c|c|}
\hline \multirow[t]{2}{*}{ Statistical indices } & \multicolumn{2}{|c|}{ Brahmaputra } & \multicolumn{2}{|c|}{ Ganges } & \multicolumn{2}{|c|}{ Meghna } \\
\hline & Calibration & Validation & Calibration & Validation & Calibration & Validation \\
\hline Nash-Sutcliffe efficiency (NSE) & 0.84 & 0.78 & 0.80 & 0.77 & 0.84 & 0.86 \\
\hline Percent bias (PBIAS) & $0.28 \%$ & $6.59 \%$ & $1.21 \%$ & $2.23 \%$ & $0.96 \%$ & $3.15 \%$ \\
\hline Root-Mean Square Error (RRMSE) & 0.32 & 0.38 & 0.60 & 0.59 & 0.38 & 0.32 \\
\hline Correlation coefficient (cc) & 0.93 & 0.89 & 0.91 & 0.89 & 0.93 & 0.94 \\
\hline Coefficient of determination $\left(R^{2}\right)$ & 0.86 & 0.79 & 0.82 & 0.79 & 0.86 & 0.88 \\
\hline
\end{tabular}

Table 5. The 22-year (1980-2001) averages of the meteorological (from the WFD forcing data) and hydrologic variables in the GBM river basins.

\begin{tabular}{lrrrr}
\hline & Unit & Brahmaputra & Ganges & Meghna \\
\hline (a) Meteorological variables & & & & \\
\hline Precipitation (Prcp) & mm year $^{-1}$ & 1609 & 1157 & 3212 \\
Temperature $\left(T_{\text {air }}\right)$ & ${ }^{\circ} \mathrm{C}$ & 9.1 & 21.7 & 23.0 \\
Net radiation (Net rad) & $\mathrm{W} \mathrm{m}^{-2}$ & 31 & 74 & 84 \\
Specific humidity & $\mathrm{g} \mathrm{kg}^{-1}$ & 9.3 & 11.8 & 14.4 \\
\hline (b) Hydrological variables & & & & \\
\hline Runoff & & 1360 & 406 & 2193 \\
Evapotranspiration (ET) & mm year $^{-1}$ & 251 & 748 & 1000 \\
Potential Evapotranspiration (PET) & mm year $^{-1}$ & 415 & 2359 & 1689 \\
\hline
\end{tabular}

(Table 5); also, the maximum (monthly) precipitation during 1980-2001 occurs in May with a magnitude of $32 \mathrm{~mm} \mathrm{day}^{-1}$, while that in the Brahmaputra and Ganges occur in July with the magnitudes of 15 and $13 \mathrm{~mm}$ day $^{-1}$, respectively. Moreover, the seasonality of runoff in all three basins corresponds well with that of precipitation. Runoff (Fig. 5j-1) in the Ganges Basin is much lower (the monthly maximum of $4.3 \mathrm{~mm} \mathrm{day}^{-1}$ in August) than in the other two basins (a monthly maximum of $9.3 \mathrm{~mm}^{\text {day }}{ }^{-1}$ in the Brahmaputra and $15.9 \mathrm{~mm} \mathrm{day}^{-1}$ in the Meghna, both in July). In addition, ET (evapotranspiration) in the Brahmaputra Basin is significantly lower $\left(251 \mathrm{~mm}_{\text {year }}{ }^{-1}\right)$ than in the other two basins $\left(748 \mathrm{~mm}_{\text {year }}{ }^{-1}\right.$ in Ganges and $1000 \mathrm{~mm} \mathrm{year}^{-1}$ in Meghna). The contrasting ET magnitudes among the three basins are due to multiple reasons: differences in elevation, amounts of surface water to evaporate, air temperature, and possibly wind and solar irradiance situations. Lower ET in the Brahmaputra Basin is likely due to its cooler air temperature, higher elevation and less vegetated area. The basinaverage normalized difference vegetation index (NDVI) in the Brahmaputra is 0.38, whereas in the Ganges and Meghna NDVI is 0.41 and 0.65 , respectively (NEO, 2014). However, the patterns of seasonal ET variability in the Brahmaputra and Meghna basins are quite similar, except there is a drop in July in the Brahmaputra (Fig. 5m-o). ET is relatively stable from May to October in the Brahmaputra and Meghna basins in contrast to that in the Ganges where ET does not reach the peak until September. Finally, both the pattern and magnitude of seasonal soil moisture variations are rather different among the three basins (Fig. 5p-r). However, the peak of soil moisture occurs consistently in August in all three basins.

Figure $5 \mathrm{~d}-\mathrm{f}$ present the 22-year mean seasonal cycle of basin-average air temperature $\left(T_{\text {air }}\right)$. The Brahmaputra Basin is much cooler (mean temperature $9.1^{\circ} \mathrm{C}$ ) than the Ganges $\left(21.7^{\circ} \mathrm{C}\right)$ and the Meghna $\left(23.0^{\circ} \mathrm{C}\right)$. Figure $5 \mathrm{~g}-\mathrm{i}$ plot the mean seasonal cycle of net radiation averaged over the three basins. The seasonal pattern of net radiation is similar, but the magnitudes differ significantly among the three basins: the average net radiation is $\sim 31,74$ and $84 \mathrm{~W} \mathrm{~m}^{-2}$ in the Brahmaputra, Ganges and Meghna basins, respectively, while the maximum (monthly-average) net radiation is $\sim 47$, 100 and $117 \mathrm{~W} \mathrm{~m}^{-2}$, respectively, in these three basins (Table 5).

\subsection{Correlation between meteorological and hydrological variables}

Figure 6 presents the scatter plots and correlation coefficients between monthly meteorological and hydrological variables in three river basins. Three different colors represent three different seasons: dry/winter (November-March), pre-monsoon (April-June), and monsoon (July-October). From this plot, the following summary can be drawn. Total runoff and surface runoff of the Brahmaputra Basin have 

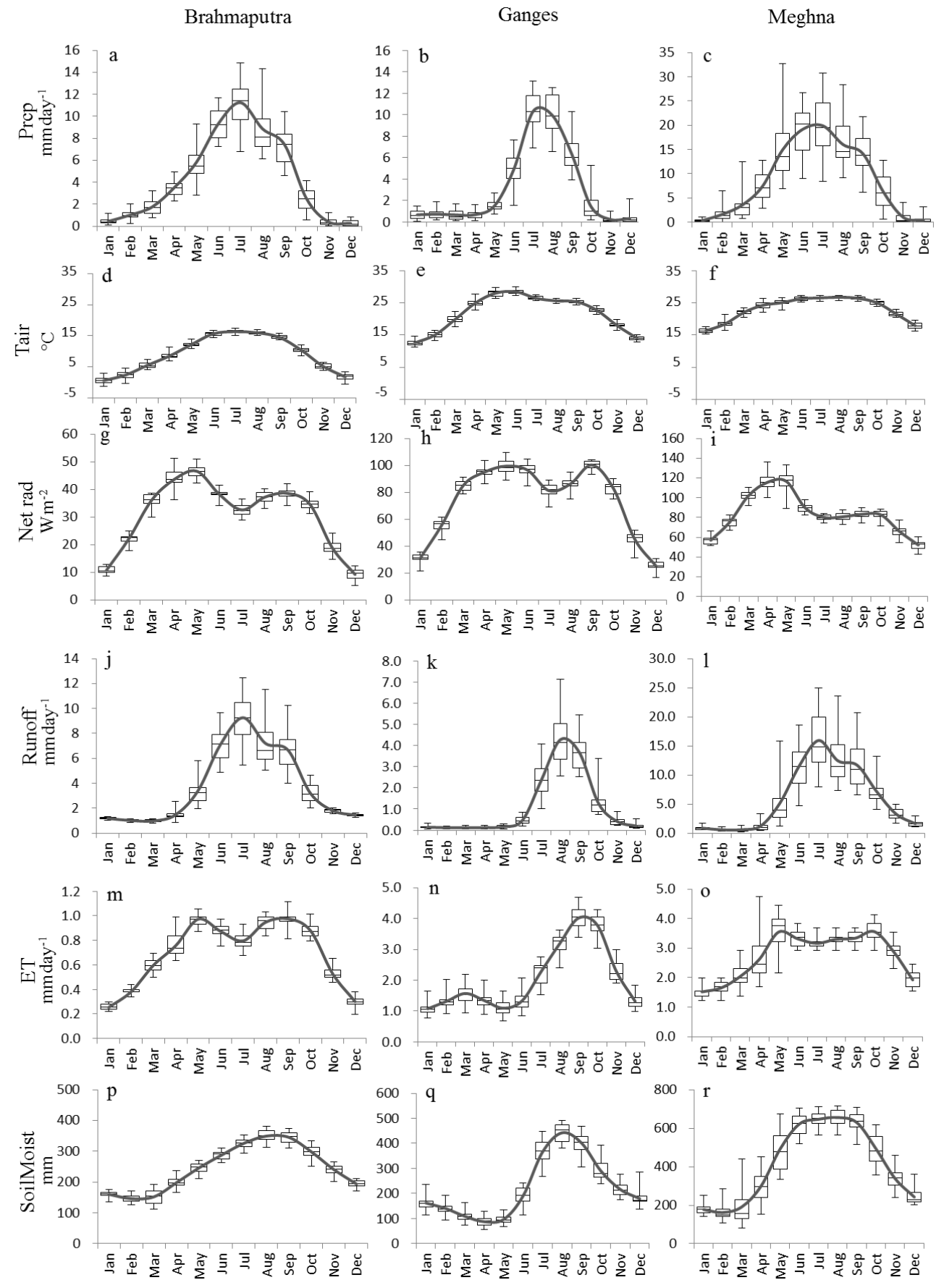

Figure 5. (a)-(r) Seasonal cycle of climatic and hydrologic quantities during 1980-2001. Box-and-whisker plots indicate minimum and maximum (whiskers), 25th and 75th percentiles (box ends), and median (black solid middle bar). Solid curve line represents the interannual average value. All abbreviated terms here refer to Table 5 .

stronger correlation $(\mathrm{cc}=0.95$ and 0.97 , both are statistically significant at $p<0.05$ ) with precipitation than the other two basins. However, subsurface runoff in the Brahmaputra Basin has weaker correlation $(\mathrm{cc}=0.62, p<0.05)$ with precipitation than that in the Ganges $(\mathrm{cc}=0.75, p<0.05)$ and Meghna ( $\mathrm{cc}=0.77, p<0.05)$. These relationships im- ply that the deeper soil depths enhance the correlation between subsurface runoff and precipitation. The deeper rootzone soil depth (calibrated $d=5 \mathrm{~m}$ ) in the Meghna Basin generates more subsurface runoff ( $69 \%$ of total runoff) than other two basins. Soil moisture in the Meghna Basin also shows stronger correlation $(\mathrm{cc}=0.87, p<0.05)$ with pre- 

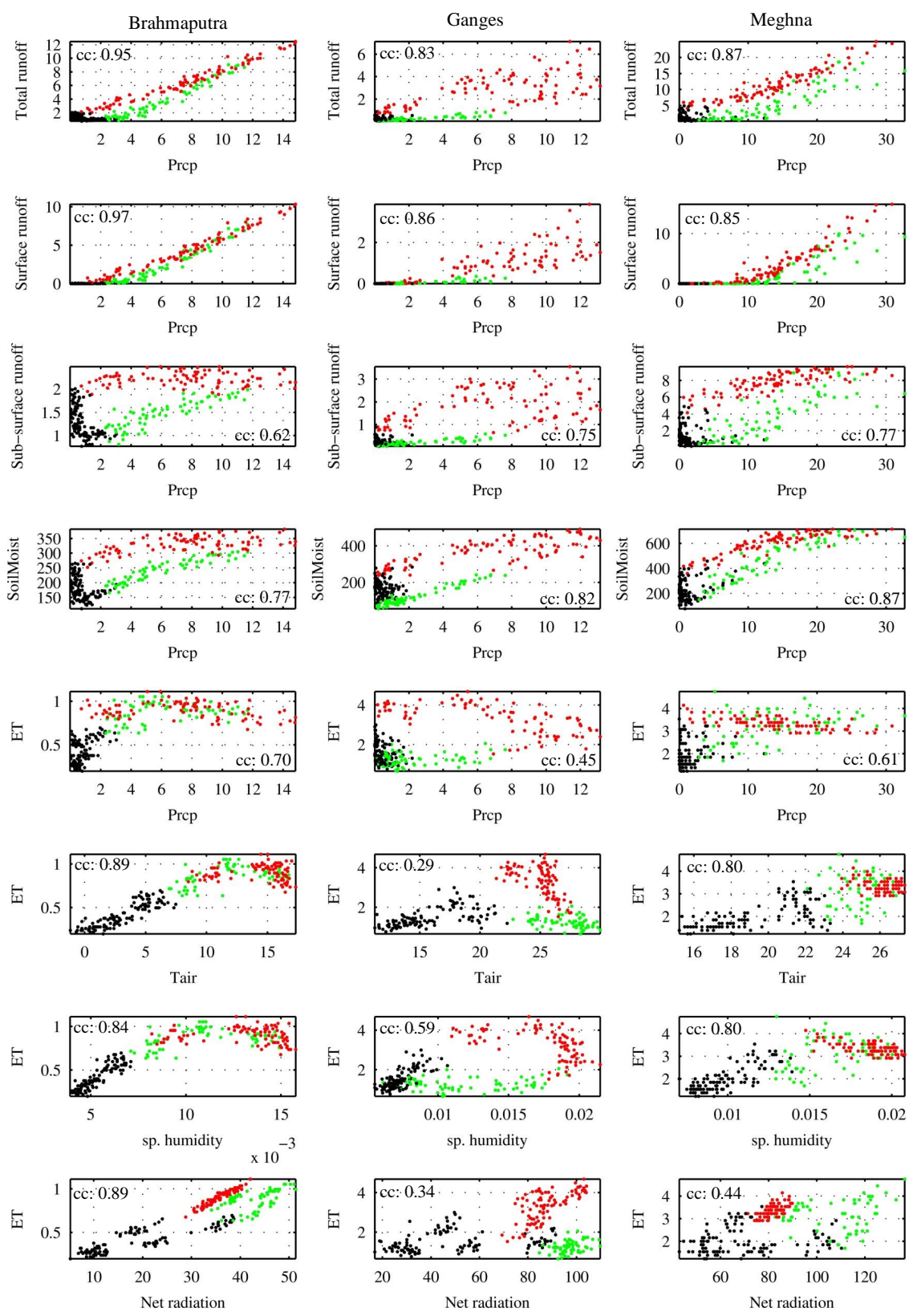

- dry/winter (November-March)

- pre-monsoon (April-June)

Figure 6. The correlation between the monthly means of meteorological variables (WFD) and that of hydrological variables for the Brahmaputra, Ganges and Meghna basins. Three different colors represent the data in three different seasons. Black: dry/winter (November-March); green: pre-monsoon (April-June); red: monsoon (July-October). The cc for each pair (all three seasons together) is noted at each subplot. The units are millimeters per day for Prcp, ET, and runoff; millimeters for SoilMoist; degrees Celcius for $T_{\text {air }}$; and watts per square meter for net radiation. All abbreviated terms here are referred to in Table 5.

cipitation than that in the Brahmaputra ( $\mathrm{cc}=0.77, p<0.05)$ and Ganges ( $\mathrm{cc}=0.82, p<0.05)$.

The relationships of evapotranspiration with various atmospheric variables (radiation, air temperature) and soil water availability are rather complex (Shaaban et al., 2011). Different methods for estimating PET in different hydrological models may also be a source of uncertainty (Thompson et al., 2014). However, the ET scheme in the H08 model uses the bulk formula where the bulk transfer coefficient is used to calculate turbulent heat fluxes (Haddeland et al., 2011). In estimating PET (and hence ET), H08 uses humidity, air temperature, wind speed and net radiation. Figure 6 presents the 
correlation of ET with different meteorological variables in three basins. The ET in the Brahmaputra has a significant correlation with precipitation, air temperature, specific humidity and net radiation with the cc ranging from 0.70 to 0.89 (all of which are statistically significant at $p<0.05)$. The correlations of ET in the Meghna Basin with the meteorological variables are also relatively strong (cc ranges from 0.61 to $0.80, p<0.05$ ) except for the net radiation ( $\mathrm{cc}=0.44$, $p<0.05$ ). However, ET in the Ganges Basin has a weak correlation with the meteorological variables (cc from 0.29 to $0.59, p<0.05)$. A weaker correlation of ET with the meteorological variables is likely attributed to the overestimation of actual ET in the Ganges Basin, because the upstream water use (which is larger in the Ganges) may be incorrectly estimated as ET by the H08 model to ensure water balance.

\subsection{Interannual variability}

Figure 7 presents the interannual variability of meteorological and hydrologic variables from simulations driven by using five different GCMs and that of the multimodel mean (shown by the thick blue line) for three basins. It can be seen from the figure that the magnitude of interannual variations of variables corresponding to individual GCMs are noticeably larger than that of the multimodel mean. However, the long-term trends in the meteorological and hydrologic variables of the multimodel mean are generally similar to that of each of the GCMs. Figure 7a1-a3 shows that the long-term trend in precipitation is not pronounced in the Brahmaputra and Meghna basins, but its interannual variability is rather large for each GCM. Among the five GCMs used, the precipitation of MRI-AGCM3 has the largest interannual variability (particularly in the Ganges and Meghna basins). A clear increasing trend in air temperature can be observed for all three basins. As there is strong correlation between precipitation and runoff (Fig. 6), the interannual variabilities of them are similar. There is no clear trend for ET in each basin from the present to the near-future periods. However, in the far-future period a notable increasing trend is observed for all basins (Fig. 7e1-e3). Figure 7f1-f3 plots the interannual variability of soil moisture. Since there are no clear trends (from the present to the near-future period) identified for precipitation and evapotranspiration, the effect of climate change on soil moisture is not pronounced.

\subsection{Projected mean changes}

The long-term average seasonal cycles of hydrometeorological variables in the two projected periods (2015-2039 and 2075-2099) were compared with that in the reference period (1979-2003). All the results presented here are from the multimodel mean of all simulations driven by the climate forcing data from five GCMs for both reference and future periods. The solid lines in Fig. 8 represent the monthly averages and the dashed lines represent the upper and lower bounds of the uncertainty bands as determined from the 10 simulations using the 10 optimal parameter sets (identified by ranking the NSE). Figure 9 plots the corresponding percentage changes and Table 6 summarizes these relative changes in the hydro-meteorological variables over the three basins on the annual and 6-month (dry season and wet season) basis.

\subsubsection{Precipitation}

Considering a high-emissions scenario, by the end of $21 \mathrm{st}$ century the long-term mean precipitation is projected to increase by $16.3,19.8$ and $29.6 \%$ in the Brahmaputra, Ganges and Meghna basins, respectively (Table 6), in agreement with previous studies which compared GCM simulation results over these regions. For example, Immerzeel (2008) estimated the increase of precipitation in the Brahmaputra Basin as 22 and $14 \%$ under the SRES A2 and B2 scenarios, respectively. Endo et al. (2012) considered the SRES A1B scenario and estimated the country-wise increase in precipitation as 19.7 and $13 \%$ for Bangladesh and India, respectively. Based on the present study, for the Brahmaputra and Meghna basins, the changes in precipitation in the dry season (November-April) are of 23 and $33.6 \%$, respectively; both are larger than the change in wet season (May-October) (Brahmaputra: $15.1 \%$; Meghna: 29\%) (Fig. 9b, c). However, the change of precipitation in the dry season in the Ganges Basin (3.6\%) is lower than that in wet season $(21.5 \%)$.

\subsubsection{Air temperature}

The GBM basin will be warmer by about $1^{\circ} \mathrm{C}$ in the near-future period (Brahmaputra: $1.2^{\circ} \mathrm{C}$; Ganges: $1.0^{\circ} \mathrm{C}$; Meghna: $0.7^{\circ} \mathrm{C}$ ) and by about $4.3^{\circ} \mathrm{C}$ in the far-future period (Brahmaputra: $4.8^{\circ} \mathrm{C}$; Ganges: $4.1^{\circ} \mathrm{C}$; Meghna: $3.8^{\circ} \mathrm{C}$ ) (Table 6). According to the projected changes, the cooler Brahmaputra Basin will be significantly warmer, with the maximum increase of up to $5.9{ }^{\circ} \mathrm{C}$ in February (Fig. 9d). In Immerzeel (2008), the increase of air temperature in the Brahmaputra Basin is projected (under the SRES A2 and B2 scenarios) as $2.3 \sim 3.5^{\circ} \mathrm{C}$ by the end of 21 st century. However, the rate of increase over the year is not uniform for all these basins. Temperature will increase more in winter than in summer (Fig. 9d-f). Therefore, a shorter winter and an extended spring can be expected in the future of the GBM basin, which may significantly affect the crop growing season as well.

\subsubsection{Runoff}

Long-term mean runoff is projected to increase by 16.2 , 33.1 and $39.7 \%$ in the Brahmaputra, Ganges and Meghna basins, respectively, by the end of the century (Table 6). Percentage increase of runoff in the Brahmaputra will be quite large in May (about 36.5\%), which may be due to the increase of precipitation and also smaller evapotranspi- 

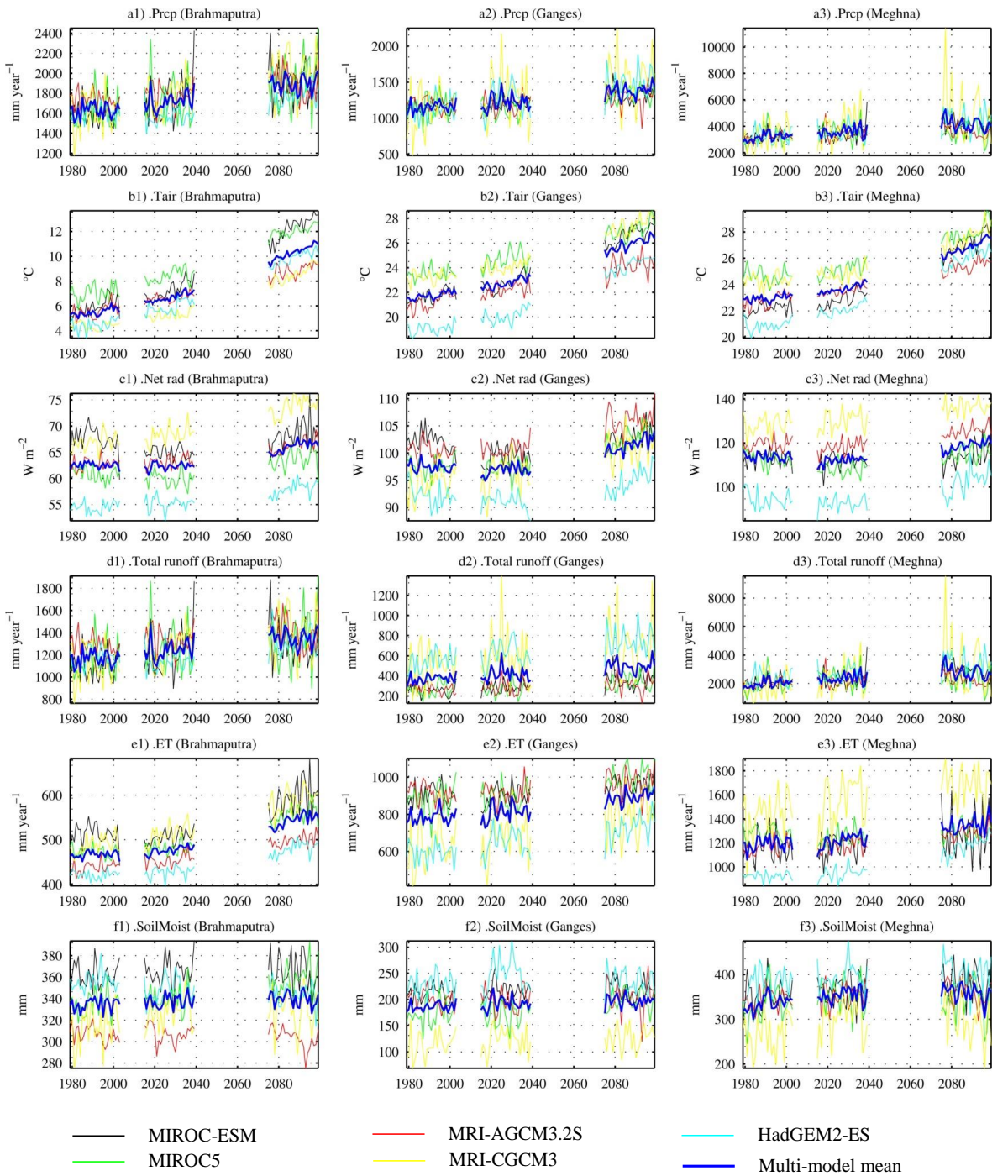

Figure 7. (a1)-(f3) Interannual variation of mean of meteorological and hydrological variables of five GCMs for the present-day (19792003), near-future (2015-2039) and far-future (2075-2099) periods. Thick blue lines represent the means of five GCMs.

ration caused by lower net radiation (Fig. 9g, m). In response to seasonally varying degrees of changes in air temperature, net radiation and evaporation, the changes of runoff in the wet season (May-October) (Brahmaputra: 20.3\%; Ganges: $36.3 \%$; Meghna: $41.8 \%$ ) are larger than in the dry season (November-April) (Brahmaputra: $2.9 \%$, Ganges: $-2.3 \%$, Meghna: 24.2\%) (Fig. 9j, k). Runoff in the Meghna Basin shows a larger response to precipitation increase, which could lead to higher possibility of floods in this basin and prolonged flooding conditions in Bangladesh. These findings are in general consistent with previous findings. Mirza (2002) reported that the probability of occurrence of 20-year floods is expected to be higher in the Brahmaputra and Meghna rivers than in Ganges river. However, Mirza et al. (2003) found that future change in the peak discharge of the Ganges River (as well as the Meghna River) is expected to be larger than that of the Brahmaputra River.

\subsubsection{Evapotranspiration}

It can be seen from Fig. 9m-o that the change of ET in the near-future period is relatively low but increases to be quite large by the end of the century (Brahmaputra: 16.4\%; Ganges: $13.6 \%$; Meghna: $12.9 \%$ ). This is due to the increase of net radiation (Brahmaputra: $5.6 \%$; Ganges: $4.1 \%$; Meghna: $4.4 \%$ ) as well as the higher air temperature. Following the seasonal patterns of radiation (Fig. 9g-i) and air temperature (Fig. 9d-f), the change of ET is expected to be considerably larger in the dry season (NovemberApril) (Brahmaputra: 25.6\%; Ganges: 19.3\%; Meghna: $18.2 \%$ ) than that in wet season (May-October) (Brahmaputra: $12.9 \%$; Ganges: $10.9 \%$; Meghna: $10.5 \%$ ). 

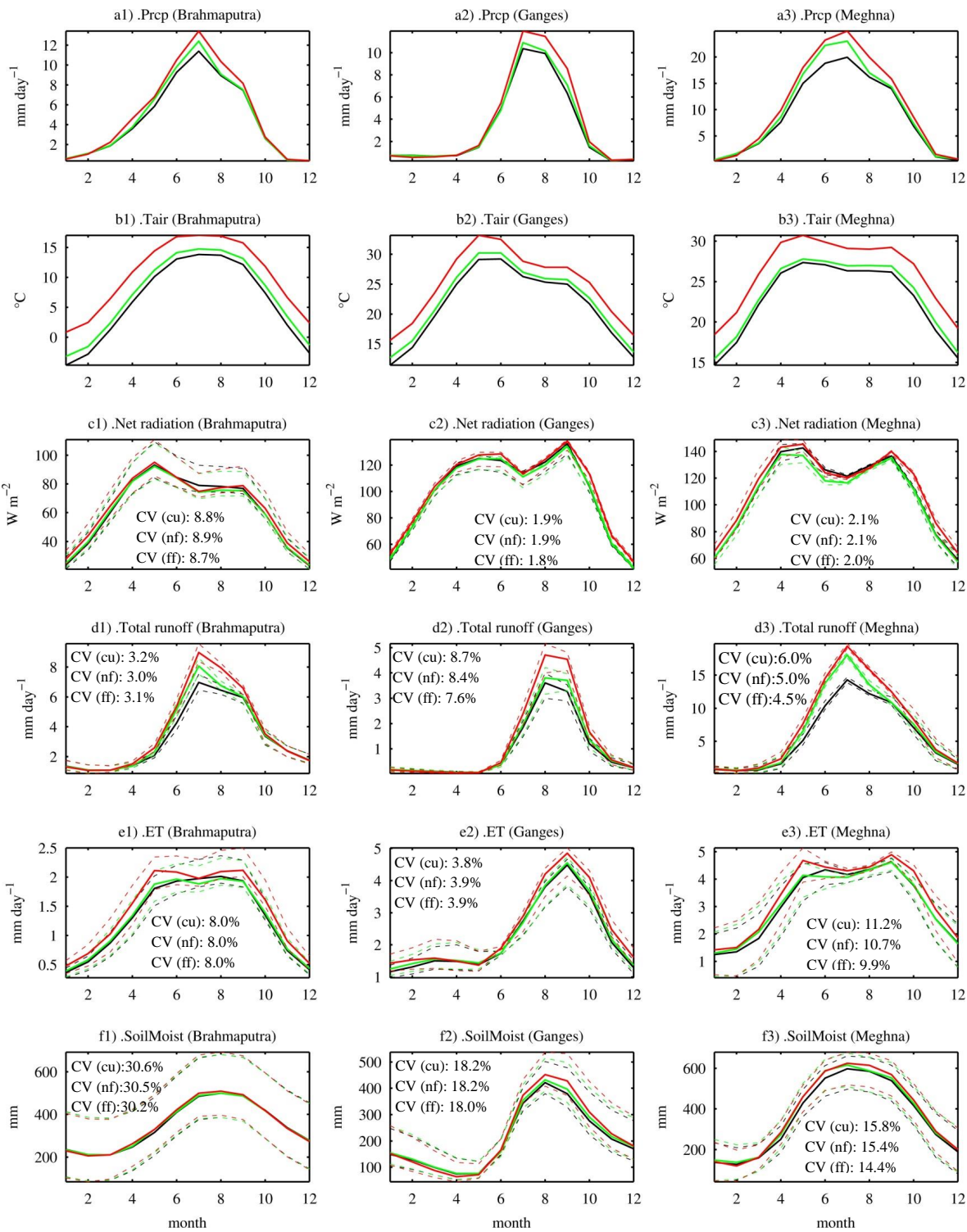

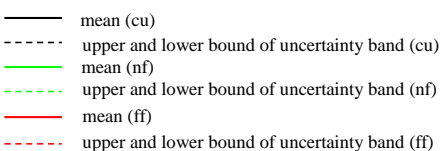

Figure 8. (a1)-(f3) The mean (solid line), upper and lower bounds (dashed line) of the uncertainty band of the hydrological quantities and net radiation components for the present-day (black), near-future (green) and far-future (red) simulations as determined found from 10 simulation results considering 10 optimal parameter sets according to NSE (cu: present-day, nf: near-future, ff: far-future). Coefficients of variations (CVs) for all periods (Table 7) are noted in each subplot.

\subsubsection{Soil moisture}

Soil moisture is expressed in terms of the water depth per unit area within the spatially varying soil depths $(3-5 \mathrm{~m})$. The change of soil moisture (ranges from 1.5-6.9\% in the farfuture) is lower compared to other hydrological quantities, except for the Meghna Basin in April where the soil moisture is projected to increase by $22 \%$. However, the associated uncertainties for all seasons are relatively high compared to other variables (Fig. 8f1-f3).

\subsubsection{Net radiation}

Net radiation is projected to increase by $>4 \%$ for all seasons except summer in the entire GBM basin by the end of the century (Fig. 9g-i). Due to the increase in the future air 
Table 6. The 10-simulation average of annual mean and percentage changes of hydrological and meteorological variables.

\begin{tabular}{|c|c|c|c|c|c|c|c|c|c|c|c|c|c|}
\hline \multirow[t]{2}{*}{ Variable } & \multirow[t]{2}{*}{ Period } & & \multicolumn{3}{|c|}{$\begin{array}{c}\text { Brahmaputra } \\
\% \text { change }\left(T_{\text {air }}:{ }^{\circ} \mathrm{C}\right)\end{array}$} & \multicolumn{4}{|c|}{$\begin{array}{c}\text { Ganges } \\
\% \text { change }\left(T_{\text {air }}:{ }^{\circ} \mathrm{C}\right)\end{array}$} & \multicolumn{4}{|c|}{$\begin{array}{c}\text { Meghna } \\
\% \text { change }\left(T_{\text {air }}:{ }^{\circ} \mathrm{C}\right)\end{array}$} \\
\hline & & 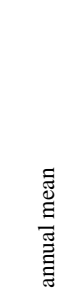 & 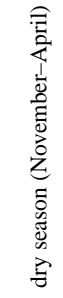 & 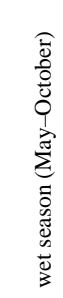 & 䄊 & 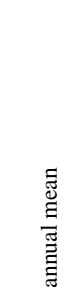 & 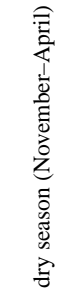 & 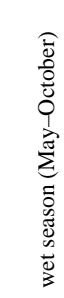 & 烝 & 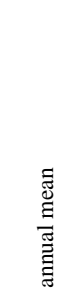 & 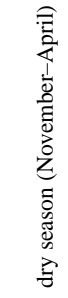 & 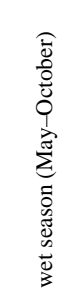 & 焉 \\
\hline \multicolumn{14}{|l|}{ (a) Meteorological variables } \\
\hline \multirow[t]{3}{*}{ Precipitation $\left(\mathrm{mm} \mathrm{year}^{-1}\right)$} & present-day (1979-2003) & 1632 & - & - & - & 1154 & - & - & - & 3192 & - & - & - \\
\hline & near-future (2015-2039) & 1720 & 4.2 & 5.6 & 5.4 & 1218 & -0.1 & 6.2 & 5.6 & 3598 & 11.4 & 12.9 & 12.7 \\
\hline & far-future (2075-2099) & 1897 & 23.0 & 15.1 & 16.3 & 1383 & 3.6 & 21.5 & 19.8 & 4139 & 33.6 & 29.0 & 29.6 \\
\hline \multirow[t]{3}{*}{$T_{\text {air }}\left({ }^{\circ} \mathrm{C}\right)$} & present-day (1979-2003) & 5.5 & - & - & - & 21.7 & - & - & - & 23.0 & - & - & - \\
\hline & near-future (2015-2039) & 6.7 & 1.4 & 1.0 & 1.2 & 22.8 & 1.1 & 0.9 & 1.0 & 23.7 & 0.8 & 0.6 & 0.7 \\
\hline & far-future (2075-2099) & 10.3 & 5.5 & 4.1 & 4.8 & 25.9 & 4.6 & 3.7 & 4.1 & 26.8 & 4.3 & 3.4 & 3.8 \\
\hline \multirow[t]{3}{*}{ Net radiation $\left(\mathrm{W} \mathrm{m}^{-2}\right)$} & present-day (1979-2003) & 63 & - & - & - & 97 & - & - & - & 114 & - & - & - \\
\hline & near-future (2015-2039) & 62 & 2.0 & -1.6 & -0.4 & 97 & -0.2 & -0.9 & -0.7 & 112 & -0.4 & -2.2 & -1.5 \\
\hline & far-future (2075-2099) & 66 & 10.3 & 3.1 & 5.6 & 101 & 5.3 & 3.4 & 4.1 & 119 & 6.5 & 3.0 & 4.4 \\
\hline \multicolumn{14}{|l|}{ (b) Hydrological variables } \\
\hline \multirow[t]{3}{*}{ Total runoff $\left(\mathrm{mm} \mathrm{year}^{-1}\right)$} & present-day (1979-2003) & 1166 & - & - & - & 372 & - & - & - & 1999 & - & - & - \\
\hline & near-future (2015-2039) & 1244 & 0.5 & 8.6 & 6.7 & 414 & 2.5 & 12.1 & 11.3 & 2380 & 10.5 & 20.2 & 19.1 \\
\hline & far-future (2075-2099) & 1355 & 2.9 & 20.3 & 16.2 & 495 & -2.3 & 36.3 & 33.1 & 2793 & 24.2 & 41.8 & 39.7 \\
\hline \multirow[t]{3}{*}{ ET $\left(\mathrm{mm}_{\mathrm{year}}{ }^{-1}\right)$} & present-day (1979-2003) & 467 & - & - & - & 785 & - & - & - & 1193 & - & - & - \\
\hline & near-future (2015-2039) & 477 & 5.5 & 0.9 & 2.1 & 808 & 4.9 & 2.1 & 3.0 & 1216 & 5.2 & 0.4 & 1.9 \\
\hline & far-future (2075-2099) & 543 & 25.6 & 12.9 & 16.4 & 892 & 19.3 & 10.9 & 13.6 & 1347 & 18.2 & 10.5 & 12.9 \\
\hline \multirow[t]{3}{*}{ Soil moisture (mm) } & present-day (1979-2003) & 335 & - & - & - & 186 & - & - & - & 336 & - & - & - \\
\hline & near-future (2015-2039) & 338 & 0.4 & 1.2 & 0.9 & 192 & 2.7 & 3.4 & 3.1 & 354 & 6.6 & 5.1 & 5.5 \\
\hline & far-future (2075-2099) & 340 & 0.2 & 2.3 & 1.5 & 197 & 0.4 & 8.3 & 5.8 & 359 & 6.7 & 6.9 & 6.9 \\
\hline
\end{tabular}

Table 7. Statistical indices (the CV and SD) of the uncertainty in model simulations due to the uncertainty in model parameters.

\begin{tabular}{|c|c|c|c|c|c|c|c|}
\hline \multirow[t]{2}{*}{ Variable } & \multirow[t]{2}{*}{ Period } & \multicolumn{2}{|c|}{ Brahmaputra } & \multicolumn{2}{|c|}{ Ganges } & \multicolumn{2}{|c|}{ Meghna } \\
\hline & & $\begin{array}{r}\text { Coefficient of } \\
\text { variation }(\mathrm{CV}) \text { of } \\
\text { mean (Fig. } 8)(\%)\end{array}$ & $\begin{array}{r}\text { Standard deviation } \\
\text { (SD) of mean } \\
\text { (Fig. 8) }\end{array}$ & $\begin{array}{r}\text { Coefficient of } \\
\text { variation }(\mathrm{CV}) \text { of } \\
\text { mean (Fig. 8) (\%) }\end{array}$ & $\begin{array}{r}\text { Standard deviation } \\
\text { (SD) of mean } \\
\text { (Fig. 8) }\end{array}$ & $\begin{array}{r}\text { Coefficient of } \\
\text { variation }(\mathrm{CV}) \text { of } \\
\text { mean (Fig. } 8)(\%)\end{array}$ & $\begin{array}{r}\text { Standard deviation } \\
(\mathrm{SD}) \text { of mean } \\
(\text { Fig. } 8)\end{array}$ \\
\hline \multirow[t]{3}{*}{ Net radiation } & present-day & 8.6 & 5.4 & 2.0 & 2.0 & 2.1 & 2.4 \\
\hline & near-future & 8.6 & 5.4 & 1.9 & 1.9 & 2.1 & 2.3 \\
\hline & far-future & 8.4 & 5.6 & 1.8 & 1.8 & 2.0 & 2.4 \\
\hline \multirow[t]{3}{*}{ Total runoff } & present-day & 3.2 & 0.1 & 7.6 & 0.1 & 6.7 & 0.4 \\
\hline & near-future & 3.0 & 0.1 & 7.2 & 0.1 & 5.4 & 0.4 \\
\hline & far-future & 3.1 & 0.1 & 6.6 & 0.1 & 4.6 & 0.4 \\
\hline \multirow[t]{3}{*}{ ET } & present-day & 7.9 & 0.1 & 3.6 & 0.1 & 11.3 & 0.4 \\
\hline & near-future & 7.9 & 0.1 & 3.7 & 0.1 & 10.6 & 0.4 \\
\hline & far-future & 7.8 & 0.1 & 3.7 & 0.1 & 9.7 & 0.4 \\
\hline \multirow[t]{3}{*}{ Soil moisture } & present-day & 31.0 & 103.7 & 18.5 & 34.5 & 15.9 & 53.5 \\
\hline & near-future & 30.8 & 104.1 & 18.5 & 35.5 & 15.4 & 54.5 \\
\hline & far-future & 30.5 & 103.7 & 18.3 & 36.1 & 14.4 & 51.6 \\
\hline
\end{tabular}

temperature, the downward long-wave radiation would increase accordingly and lead to the increase in net radiation. However, the change of net radiation in the far-future period is larger in the dry season (Brahmaputra: 10.3\%; Ganges: $5.3 \%$; Meghna: $6.5 \%$ ) than in the wet season (Brahmaputra: $3.1 \%$; Ganges: $3.4 \%$; Meghna: $3 \%$ ). For the near-future period, net radiation is projected to decrease by $<1 \%$ through almost all seasons due to the smaller increase in air temperature $\left(\sim 1^{\circ} \mathrm{C}\right)$ as well as decreased incoming solar radiation (not shown) in this basin.

\subsection{Uncertainty in projection due to model parameters}

In recent decades, along with the increasing computational power there has been a trend towards increasing complexity 

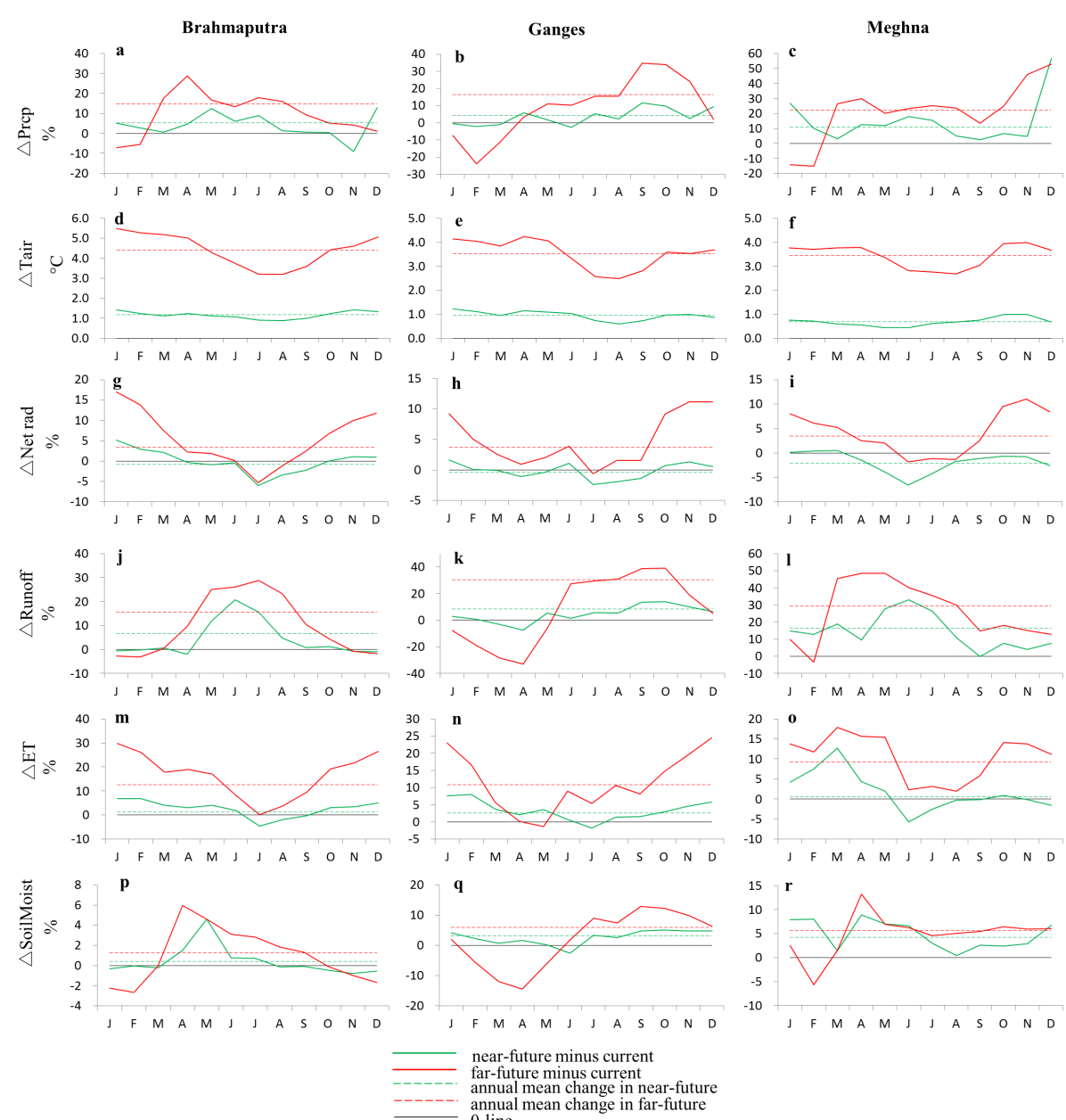

0 -line

Figure 9. (a)-(r) Percentage changes in the monthly means of the climatic and hydrologic quantities from the present-day period to the near-future and far-future periods. The dashed lines represent the annual mean changes.

of hydrological models to capture natural phenomena more precisely. However, the increased complexity of hydrological models does not necessarily improve their performance for unobserved conditions due to the uncertainty in the model parameter values (Carpenter and Georgakakos, 2006; Tripp and Niemann, 2008). An increase in complexity may improve the calibration performance due to the increased flexibility in the model behavior, but the ability to identify correct parameter values is typically reduced (Wagener et al., 2003). Model simulations with multiple combinations of parameter sets can perform equally well in reproducing the observations. Another source of uncertainty comes from the assumption of stationary model parameters, which is one of the major limitations in modeling the effects of climate change. Model parameters are commonly estimated under the current climate conditions as a basis for predicting future conditions, but the optimal parameters may not be stationary over time (Mirza and Ahmad, 2005). Therefore, the uncertainty in future projections due to model parameter specification can be critical (Vaze et al., 2010; Merz et al., 2011; Coron et al.,
2012), although it is usually ignored in most climate change impact studies (Lespinas et al., 2014). Results obtained by Vaze et al. (2010) indicated that the model parameters can generally be used for climate impact studies when a model is calibrated using more than 20 years of data and where the future precipitation is not more than $15 \%$ lower or $20 \%$ higher than that in the calibration period. However, Coron et al. (2012) found a significant number of errors in simulations due to this uncertainty and suggested further research to improve the methods of diagnosing parameter transferability under the changing climate. For the purpose of minimizing this parameter uncertainty, the average results from the 10 simulations using 10 optimal parameter sets are considered as the simulation result for the two future periods in this study. Also, the propagating uncertainty in simulation results due to the uncertainty in mode parameters will be quantified and compared among various hydrologic variables in this study.

The upper and lower bounds of the uncertainty of hydrometeorological variables are plotted in Fig. 8 for all the sim- 
ulation periods. It can be seen from the figure that the uncertainty band of runoff is relatively narrow, which indicates that future runoff is well predictable through model simulations. The uncertainty due to model parameters in runoff projection is lower (the $\mathrm{CV}$ ranges between 3 and $7.6 \%$ among three basins) than that of other hydrologic variables (Table 7 , Fig. 8d1-d3). In addition, in Fig. 4e it is observed that there is no significant uncertainty in simulated peak discharge for the Brahmaputra and Meghna rivers. Lower uncertainty in simulating runoff is highly desirable for climate change impact studies; for instance, the flood risk assessment where the runoff estimate (especially the peak flow) is the main focus. However, a relatively wide uncertainty band of runoff can be found in the Ganges Basin during the wet season (Fig. 8d2), which might be due to the fact that the upstream water use (diversion) in the Ganges was not well represented in the model. Notice that the lower uncertainty in runoff projection relative to other variables could be expected as the model was calibrated and validated against observed streamflow at the basin outlet. The uncertainty in ET projection is also lower (CV: 3.6-11.3\%; SD: 0.1-0.4), which can be related to the narrower uncertainty band of net radiation (CV: $1.8-8.6 \%$; SD: $1.8-5.6)$. On the other hand, the projection of soil moisture is rather uncertain for all three basins (CV: 14.4-31\%; SD: 35-104). Large uncertainty in predicting soil moisture can be a serious issue which is significant in land use management and agriculture. This emphasizes the critical significance of (1) suitable parameterization of soil water physics in the model, (2) a reliable regional soil map for the specification of model parameters, and (3) soil moisture observations for model calibration and validation.

\section{Conclusions}

This study presents model analyses of the climate change impact on the Ganges-Brahmaputra-Meghna (GBM) basin focusing on (1) the setup of a hydrologic model by integrating the fine-resolution $(\sim 0.5 \mathrm{~km})$ DEM data for the accurate river network delineation to simulate at relatively fine grid resolution $(10 \mathrm{~km})(2)$ the calibration and validation of the hydrologic model with long-term observed daily discharge data and (3) the impacts of future climate changes in the basin-scale hydrology. The uncertainties in the future projection stemming from model parameters were also assessed. The time-slice numerical experiments were performed using the model forced by the climatic variables from five GCMs (all participating in the CMIP5) for the present-day (19792003), near-future (2015-2039) and the far-future (20752099) periods.

The following findings and conclusions were drawn from the model analysis:

- (a) The entire GBM basin is projected to be warmer, in the range of $1-4.3^{\circ} \mathrm{C}$ in the near-future and farfuture periods. The cooler Brahmaputra Basin will be warmer than the Ganges and Meghna. (b) Considering a high-emissions scenario, by the end of 21 st century the long-term mean precipitation is projected to increase by $+16.3,+19.8$ and $+29.6 \%$, and the long-term mean runoff is projected to increase by $+16.2,+33.1$ and $+39.7 \%$ in the Brahmaputra, Ganges and Meghna basins, respectively. (c) The change of ET in the nearfuture is relatively low, but increases to be quite large by the end of the century due to the increase of net radiation as well as the higher air temperature. However, the change will be considerably larger in the dry season than in the wet season. (d) The change of soil moisture is lower compared to other hydrological quantities.

- Overall, it is observed that the climate change impact on the hydrological processes of the Meghna Basin is larger than that in the other two basins. For example, in the near-future period runoff in the Meghna Basin is projected to increase by $19.1 \%$ whereas it is projected to increase by 6.7 and $11.3 \%$ for the Brahmaputra and Ganges, respectively. In the far-future period, a larger increase of precipitation $(29.6 \%)$, lower increase of ET $(12.9 \%)$ and consequently larger increase of runoff $(39.7 \%)$ lead to a higher possibility of floods in this basin.

- The uncertainty due to model parameters in runoff projection is lower than that of other hydrologic variables. The uncertainty in ET projection is also lower, which can be related to the narrower uncertainty band of net radiation. On the other hand, the projection of soil moisture is rather uncertain in all three basins, which can be significant in land use management and agriculture in particular. This emphasizes the significance of (1) suitable parameterization of soil water physics in the model, (2) a reliable regional soil map for the specification of model parameters, and (3) soil moisture observations for model calibration and validation.

However, this study still has some limitations which can be addressed in future research. (a) All results presented here are basin-averaged. The basin-averaged large-scale changes and trends are difficult to translate to regional- and local-scale impacts. Moreover, the changes in averages do not reflect the changes in variability and extremes, (b) anthropogenic and industrial water use upstream are important factors in altering the hydrologic cycle; however, they were not considered in the present study due to data constraints, (c) urbanizing watersheds are characterized by rapid land use changes and the associated landscape disturbances can shift the rainfallrunoff relationships away from natural processes. Hydrological changes in future can also be amplified by changing land uses. However, in our study future changes of demography and land uses were not considered. 
Appendix A: Model validation at three upstream station

The model performance was further evaluated by comparing the simulated monthly streamflow with the observed data from the Global Runoff Data Centre (GRDC) at three upstream gauging stations (Farakka, Pandu and Teesta) in the GBM basin. The locations and drainage areas of these three stations are summarized in Table 3. Although the available data period does not cover the study period 1980-2001 (except for the Teesta which has the data from 1985 to 1991), the mean seasonal cycle and the mean, maximum, minimum, and the standard deviation of the streamflow are compared in Fig. A1 and Table A1. It can be seen that the mean seasonal cycle of simulated streamflow matches well with the corresponding GRDC data (Fig. A1d-f). Also, the agreement of the simulated and observed 1985-1991 monthly streamflow at the Teesta station of the Brahmaputra Basin is excellent (Fig. A1c). 
Table A1. Comparison between observed (data source: GRDC) and simulated discharge $\left(\mathrm{m}^{3} \mathrm{~s}^{-1}\right)$ at the Farakka gauging station in the Ganges Basin, and Pandu and Teesta stations in the Brahmaputra Basin.

\begin{tabular}{lrrrrrr}
\hline $\begin{array}{l}\text { Basin } \\
\text { Station }\end{array}$ & \multicolumn{2}{c}{$\begin{array}{c}\text { Ganges } \\
\text { Farakka }\end{array}$} & \multicolumn{2}{c}{$\begin{array}{c}\text { Brahmaputra } \\
\text { Pandu }\end{array}$} & \multicolumn{2}{c}{$\begin{array}{c}\text { Brahmaputra } \\
\text { Teesta }\end{array}$} \\
\hline $\begin{array}{l}\text { Data type } \\
\text { Data period } \\
\text { (with missing) }\end{array}$ & $\begin{array}{r}\text { observed } \\
\text { Mean }\end{array}$ & simulated & observed & simulated & observed & simulated \\
Me-1973 & $1980-2001$ & $1975-1979$ & $1980-2001$ & $1969-1992$ & $1980-2001$ \\
Maximum & 12037 & 11399 & 18818 & 15868 & 915 & 920 \\
Minimum & 65072 & 69715 & 49210 & 46381 & 3622 & 4219 \\
Standard deviation & 1181 & 414 & 4367 & 3693 & 10 & 122 \\
\hline
\end{tabular}
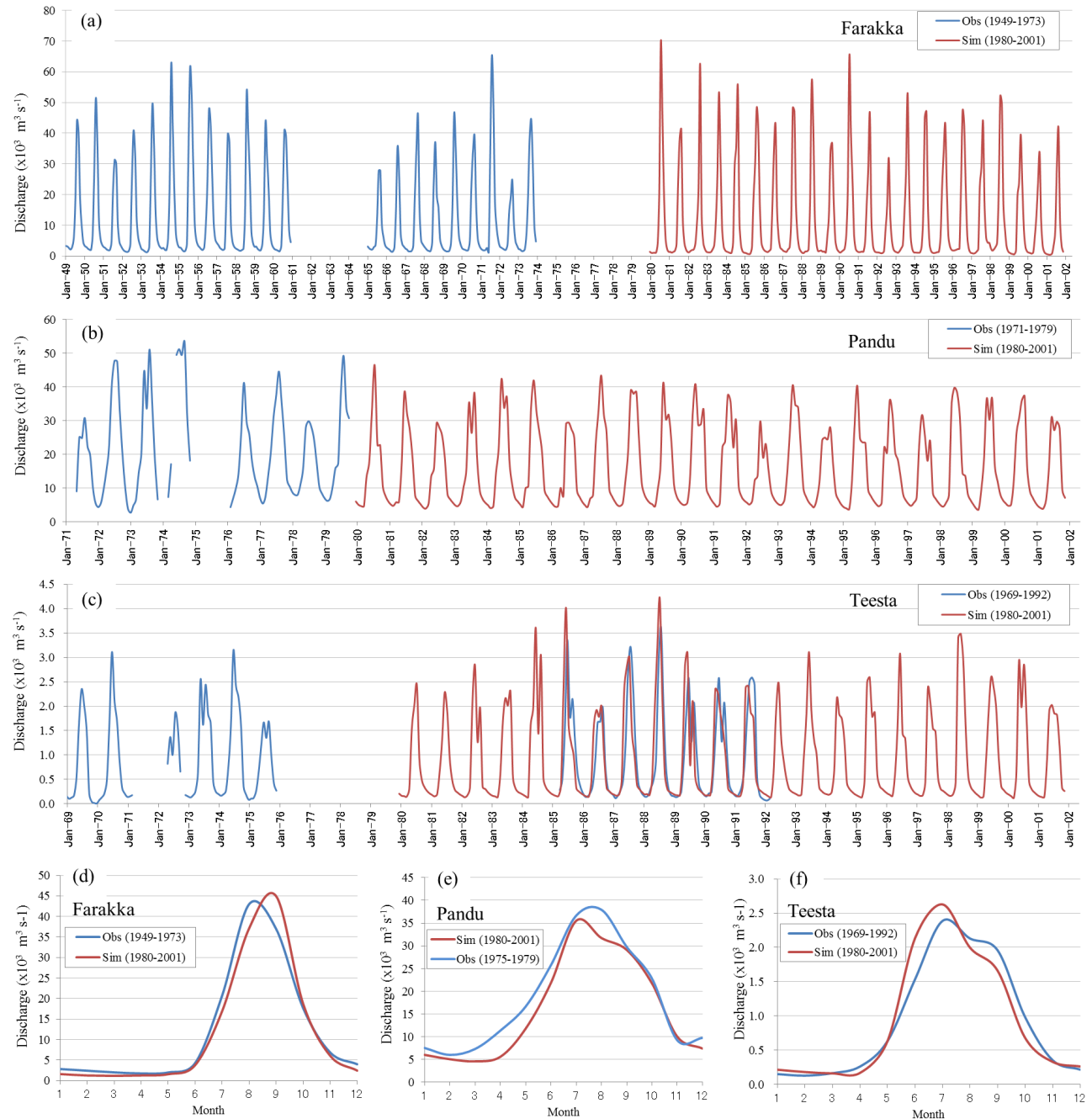

Figure A1. Comparisons between simulated (magenta line) and observed GRDC (blue line) data for (a)-(c) the monthly time series of discharges and (d)-(f) long-term mean seasonal cycles at the Farakka gauging station in the Ganges Basin and the Pundu and Teesta stations in the Brahmaputra Basin. 


\section{Appendix B}

Table B1. Salient features of CMIP5 climate models used in the analysis.

\begin{tabular}{|c|c|c|c|c|c|}
\hline Model name & MIROC-ESM & MIROC5 & MRI-AGCM3.2S & MRI-CGCM3 & HadGEM2-ES \\
\hline Modeling center & $\begin{array}{l}\text { Japan Agency for Marine- } \\
\text { Earth Science and Technol- } \\
\text { ogy, Atmosphere and Ocean } \\
\text { Research Institute (The Uni- } \\
\text { versity of Tokyo), and Na- } \\
\text { tional Institute for Environ- } \\
\text { mental Studies }\end{array}$ & $\begin{array}{l}\text { Atmosphere and Ocean Re- } \\
\text { search Institute (The Uni- } \\
\text { versity of Tokyo), National } \\
\text { Institute for Environmental } \\
\text { Studies, and Japan Agency } \\
\text { for Marine-Earth Science } \\
\text { and Technology }\end{array}$ & $\begin{array}{l}\text { Meteorological } \\
\text { Research Institute } \\
\text { (MRI), Japan and } \\
\text { Japan Meteorological } \\
\text { Agency (JMA), Japan }\end{array}$ & $\begin{array}{l}\text { Meteorological } \\
\text { Research Institute } \\
\text { (MRI), Japan }\end{array}$ & $\begin{array}{l}\text { Met Office Hadley } \\
\text { Centre, UK }\end{array}$ \\
\hline Scenario & RCP 8.5 & RCP 8.5 & SRES A1B & RCP 8.5 & RCP 8.5 \\
\hline Nominal horizontal resolution & $2.81 \times 2.77^{\circ}$ & $1.41 \times 1.39^{\circ}$ & $0.25 \times 0.25^{\circ}$ & $1.125 \times 1.11^{\circ}$ & $1.875 \times 1.25^{\circ}$ \\
\hline Model type & $\mathrm{ESM}^{\mathrm{a}}$ & $\mathrm{ESM}^{\mathrm{a}}$ & AMIP & $\mathrm{ESM}^{\mathrm{a}}$ & $\mathrm{ESM}^{\mathrm{a}}$ \\
\hline Aerosol component name or type & SPRINTARS & SPRINTARS & Prescribed & & Interactive \\
\hline Atmospheric Chemistry & Not implemented & Not implemented & Not implemented & Not implemented & Included \\
\hline Land surface component & MATSIRO & MATSIRO & SiB0109 & HAL & Included \\
\hline Ocean Biogeochemistry & NPZD-type & Not implemented & Not implemented & Not implemented & Included \\
\hline Sea ice & Included & Included & Not implemented & Included & Included \\
\hline
\end{tabular}

surface temperature and sea ice extent. 
Acknowledgements. This study is supported by the Public Works Research Institute (PWRI), Japan. The first author is indebted to the authority of Nippon Koei Co., Ltd., Japan, for the grant from The Kubota Fund. Also, thanks are given to A. Hasegawa, and T. Sayama for help in data preparation and for suggestions, and to the Bangladesh Water Development Board (BWDB) for providing observed hydrological data. Finally, the authors wish to thank the editor and five anonymous reviewers for their constructive comments and suggestions, which greatly improved the quality of the paper.

Edited by: F. Tian

\section{References}

Abrams, P.: River Ganges, available at: http://www.africanwater. org/ganges.htm (last access date: 13 July 2014), 2003.

Biemans, H., Speelman, L. H., Ludwig, F., Moors, E. J., Wiltshire, A. J., Kumar, P., Gerten, D., and Kabat, P.: Future water resources for food production in five South Asian river basins and potential for adaptation - A modeling study, Sci. Total Environ., 468-469, Supplement, S117-S131, doi:10.1016/j.scitotenv.2013.05.092, 2013.

BWDB: Rivers of Bangladesh, Bangladesh Water Development Board, Dhaka, 2012.

Carpenter, T. M. and Georgakakos, K. P.: Intercomparison of lumped versus distributed hydrologic model ensemble simulations on operational forecast scales, J. Hydrol., 329, 174-185, doi:10.1016/j.jhydrol.2006.02.013, 2006.

Chowdhury, M. R.: An Assessment of Flood Forecasting in Bangladesh: The Experience of the 1998 Flood, Nat. Hazards, 139-163, 2000.

Chowdhury, M. R. and Ward, M. N.: Hydro-meteorological variability in the greater Ganges-Brahmaputra-Meghna basins, Int. J. Climatol., 24, 1495-1508, doi:10.1002/joc.1076, 2004.

Chowdhury, M. R. and Ward, M. N.: Seasonal flooding in Bangladesh - variability and predictability, Hydrol. Process., 21, 335-347, doi:10.1002/hyp.6236, 2007.

Coron, L., Andréassian, V., Perrin, C., Lerat, J., Vaze, J., Bourqui, M., and Hendrickx, F.: Crash testing hydrological models in contrasted climate conditions: An experiment on 216 Australian catchments, Water Resour. Res., 48, W05552, doi:10.1029/2011wr011721, 2012.

Endo, H., Kitoh, A., Ose, T., Mizuta, R., and Kusunoki, S.: Future changes and uncertainties in Asian precipitation simulated by multiphysics and multi-sea surface temperature ensemble experiments with high-resolution Meteorological Research Institute atmospheric general circulation models (MRI-AGCMs), J. Geophys. Res., 117, D16118, doi:10.1029/2012jd017874, 2012.

FAO-AQUASTAT: Ganges-Brahmaputra-Meghna River Basin, available at: http://www.fao.org/nr/water/aquastat/basins/gbm/ index.stm, last access: 19 April 2014.

Gain, A. K., Immerzeel, W. W., Sperna Weiland, F. C., and Bierkens, M. F. P.: Impact of climate change on the stream flow of the lower Brahmaputra: trends in high and low flows based on discharge-weighted ensemble modelling, Hydrol. Earth Syst. Sci., 15, 1537-1545, doi:10.5194/hess-15-1537-2011, 2011.
Ghosh, S. and Dutta, S.: Impact of climate change on flood characteristics in Brahmaputra basin using a macro-scale distributed hydrological model, J. Earth Syst. Sci., 121, 637-657, doi:10.1007/s12040-012-0181-y, 2012.

Haddeland, I., Clark, D. B., Franssen, W., Ludwig, F., Voß, F., Arnell, N. W., Bertrand, N., Best, M., Folwell, S., Gerten, D., Gomes, S., Gosling, S. N., Hagemann, S., Hanasaki, N., Harding, R., Heinke, J., Kabat, P., Koirala, S., Oki, T., Polcher, J., Stacke, T., Viterbo, P., Weedon, G. P., and Yeh, P.: Multimodel Estimate of the Global Terrestrial Water Balance: Setup and First Results, J. Hydrometeorol., 12, 869-884, doi:10.1175/2011jhm1324.1, 2011.

Haddeland, I., Heinke, J., Voß, F., Eisner, S., Chen, C., Hagemann, S., and Ludwig, F.: Effects of climate model radiation, humidity and wind estimates on hydrological simulations, Hydrol. Earth Syst. Sci., 16, 305-318, doi:10.5194/hess-16-305-2012, 2012.

Hanasaki, N., Kanae, S., Oki, T., Masuda, K., Motoya, K., Shirakawa, N., Shen, Y., and Tanaka, K.: An integrated model for the assessment of global water resources - Part 1: Model description and input meteorological forcing, Hydrol. Earth Syst. Sci., 12, 1007-1025, doi:10.5194/hess-12-1007-2008, 2008.

Hanasaki, N., Saito, Y., Chaiyasaen, C., Champathong, A., Ekkawatpanit, C., Saphaokham, S., Sukhapunnaphan, T., Sumdin, S., and Thongduang, J.: A quasi-real-time hydrological simulation of the Chao Phraya River using meteorological data from the Thai Meteorological Department Automatic Weather Stations, Hydrol. Res. Lett., 8, 9-14, doi:10.3178/hrl.8.9, 2014.

Hydrological data and maps based on SHuttle Elevation Derivatives at multiple Scales, available at: http://hydrosheds.cr.usgs. gov/hydro.php, last access: 19 April 2014.

Immerzeel, W.: Historical trends and future predictions of climate variability in the Brahmaputra basin, I. J. Climatol., 28, 243-254, doi:10.1002/joc.1528, 2008.

Inomata, H., Takeuchi, K., and Fukami, K.: Development of a Statistical Bias Correction Method For Daily Precipitation Data of GCM20, J. Japan Soc. Civil Eng., 67, I_247-I_252, doi:10.2208/jscejhe.67.I_247, 2011.

Islam, A. S., Haque, A., and Bala, S. K.: Hydrologic characteristics of floods in Ganges-Brahmaputra-Meghna (GBM) delta, Nat. Hazards, 54, 797-811, 2010.

IWM: Updating and Validation of North West Region Model (NWRM), Institute of Water Modelling, Bangladesh, 2006.

Kamal-Heikman, S., Derry, L. A., Stedinger, J. R., and Duncan, C. C.: A Simple Predictive Tool for Lower Brahmaputra River Basin Monsoon Flooding, Earth Inter., 11, 1-11, doi:10.1175/ei226.1, 2007.

Kamal, R., Matin, M. A., and Nasreen, S.: Response of River Flow Regime to Various Climate Change Scenarios in GangesBrahmaputra- Meghna Basin, J. Water Resour. Ocean Sci., 2, 1524, doi:10.11648/j.wros.20130202.12, 2013.

Kwak, Y., Takeuchi, K., Fukami, K., and Magome, J.: A new approach to flood risk assessment in Asia-Pacific region based on MRI-AGCM outputs, Hydrol. Res. Lett., 6, 70-75, doi:10.3178/HRL.6.70, 2012.

Lehner, B., Liermann, C. R., Revenga, C., Vörösmarty, C., Fekete, B., Crouzet, P., Döll, P., Endejan, M., Frenken, K., Magome, J., Nilsson, C., Robertson, J. C., Rödel, R., Sindorf, N., and Wisser, D.: High-resolution mapping of the world's reservoirs and dams 
for sustainable river-flow management, Frontiers in Ecology and the Environment, 9, 494-502, doi:10.1890/100125, 2011.

Lehner, B., Verdin, K., and Jarvis, A.: HydroSHEDS technical documentation v1.0, World Wildlife Fund US, Washington, DC, 127, 2006.

Lespinas, F., Ludwig, W., and Heussner, S.: Hydrological and climatic uncertainties associated with modeling the impact of climate change on water resources of small Mediterranean coastal rivers, J. Hydrol., 511, 403-422, doi:10.1016/j.jhydrol.2014.01.033, 2014.

Lucas-Picher, P., Christensen, J. H., Saeed, F., Kumar, P., Asharaf, S., Ahrens, B., Wiltshire, A. J., Jacob, D., and Hagemann, S.: Can Regional Climate Models Represent the Indian Monsoon?, J. Hydrometeorol., 12, 849-868, doi:10.1175/2011jhm1327.1, 2011.

Manabe, S.: Climate and the ocean circulation - 1: The atmospheric circulation and the hydrology of the Earth's surface, Mon. Weather Rev., 97, 739-774, 1969.

Merz, R., Parajka, J., and Blöschl, G.: Time stability of catchment model parameters: Implications for climate impact analyses, Water Resour. Res., 47, W02531, doi:10.1029/2010wr009505, 2011.

Mirza, M. M. Q., Warrick, R. A., Ericksen, N. J., and Kenny, G. J.: Trends and persistence in precipitation in the Ganges, Brahmaputra and Meghna river basins, Hydrol. Sci. J., 43, 345-858, 1998.

Mirza, M. M. Q.: Global warming and changes in the probability ofoccurrence of floods in Bangladesh and implications, Global Environ. Change, 12, 127-138, 2002.

Mirza, M. M. Q.: Three Recent Extreme Floods in Bangladesh: A Hydro-Meteorological Analysis, Nat. Hazards, 28, 35-64, doi:10.1023/A:1021169731325, 2003.

Mirza, M. M. Q., Warrick, R. A., and Ericksen, N. J.: The implications of climate change on floods of the Ganges, Brahmaputra and Meghna rivers in Bangladesh, Clim. Change, 57, 287-318, 2003.

Mirza, M. M. Q. and Ahmad, Q. K.: Climate Change And Water Resources, in: South Asia, edited by: Monirul Qader Mirza, M., Q. K. A., A. A. Balkema Publishers, Leiden, the Netherlands, 2005.

Mizuta, R., Yoshimura, H., Murakami, H., Matsueda, M., Endo, H., Ose, T., Kamiguchi, K., Hosaka, M., Sugi, M., Yukimoto, S., Kusunoki, S., and Kitoh, A.: Climate Simulations Using MRIAGCM3.2 with 20-km Grid, J. Meteorol. Soc. Japan, 90A, 233258, doi:10.2151/jmsj.2012-A12, 2012.

Nash, J. E. and Sutcliffe, J. V.: River flow forecasting through conceptual models part I - a discussion of principles, J. Hydrol., 10, 282-290, 1970.

NEO: Vegetation Index [NDVI] (1 Month - Terra/Modis), available at: http://neo.sci.gsfc.nasa.gov/view.php?datasetId=MOD13A2_ M_NDVI\&year=2000, last access: 19 April 2014.

Nishat, A. and Faisal, I. M.: An assessment of the Institutional Mechanism for Water Negotiations in the Ganges-BrahmaputraMeghna system, Int. Negotiations, 5, 289-310, 2000.

Nishat, B. and Rahman, S. M. M.: Water Resources Modeling of the Ganges-Brahmaputra-Meghna River Basins Using Satellite Remote Sensing Data, JAWRA J. Am. Water Resour. Assoc., 45, 1313-1327, doi:10.1111/j.1752-1688.2009.00374.x, 2009.

Oki, T. and Sud, Y. C.: Design of Total Runoff Integrating Pathways (TRIP)-A Global River Channel Network, Earth Inter., 2, EI013, 1998.
Pfly: Ganges-Brahmaputra-Meghna basins.jpg, available at: http: //en.wikipedia.org/wiki/File:Ganges-Brahmaputra-Meghna_ basins.jpg\# (last access: April 2014), 2011.

Pokhrel, Y., Hanasaki, N., Koirala, S., Cho, J., Yeh, P. J. F., Kim, H., Kanae, S., and Oki, T.: Incorporating Anthropogenic Water Regulation Modules into a Land Surface Model, J. Hydrometeorol., 13, 255-269, doi:10.1175/jhm-d-11-013.1, 2012.

Rahman, M. M., Ferdousi, N., Sato, Y., Kusunoki, S., and Kitoh, A.: Rainfall and temperature scenario for Bangladesh using 20 km mesh AGCM, International J. Clim. Change Strat. Manage., 4, 66-80, doi:10.1108/17568691211200227, 2012.

Sevat, E. and Dezetter, A.: Selection of calibration objective functions in the context of rainfall-runoff modeling in a Sudanese savannah area, Hydrological Sci. J., 36, 307-330, 1991.

Shaaban, A. J., Amin, M. Z. M., Chen, Z. Q., and Ohara, N.: Regional Modeling of Climate Change Impact on Peninsular Malaysia Water Resources, J. Hydrol. Eng., 16, 1040-1049, doi:10.1061/(ASCE)HE.1943-5584.0000305, 2011.

Siderius, C., Biemans, H., Wiltshire, A., Rao, S., Franssen, W. H., Kumar, P., Gosain, A. K., van Vliet, M. T., and Collins, D. N.: Snowmelt contributions to discharge of the Ganges, The Sci. Total Environ., 468-469 Supplement, S93-S101, doi:10.1016/j.scitotenv.2013.05.084, 2013.

Taylor, K. E., Stouffer, R. J., and Meehl, G. A.: An overview of CMIP5 and the experimental design, B. Am. Meteorol. Soc., 93, 485-498, doi:10.1175/BAMS-D-11-00094.1, 2012.

Tateishi, R., Hoan, N. T., Kobayashi, T., Alsaaideh, B., Tana, G., and Phong, D. X.: Production of Global Land Cover Data - GLCNMO2008, J. Geogr. Geol., 6, 99-122, doi:10.5539/jgg.v6n3p99, 2014.

Thompson, J. R., Green, A. J., and Kingston, D. G.: Potential evapotranspiration-related uncertainty in climate change impacts on river flow: An assessment for the Mekong River basin, J. Hydrol., 510, 259-279, doi:10.1016/j.jhydrol.2013.12.010, 2014.

Tripp, D. R. and Niemann, J. D.: Evaluating the parameter identifiability and structural validity of a probabilitydistributed model for soil moisture, J. Hydrol., 353, 93-108, doi:10.1016/j.jhydrol.2008.01.028, 2008.

Vaze, J., Post, D. A., Chiew, F. H. S., Perraud, J. M., Viney, N. R., and Teng, J.: Climate non-stationarity - Validity of calibrated rainfall-runoff models for use in climate change studies, J. Hydro., 394, 447-457, doi:10.1016/j.jhydrol.2010.09.018, 2010

Wagener, T., McIntyre, N., Lees, M. J., Wheater, H. S., and Gupta, H. V.: Towards reduced uncertainty in conceptual rainfall-runoff modelling: dynamic identifiability analysis, Hydrol. Process., 17, 455-476, doi:10.1002/hyp.1135, 2003.

Weedon, G. P., Gomes, S., Viterbo, P., Österle, H., Adam, J. C., Bellouin, N., Boucher, O., and Best, M.: The watch forcing data 1958-2001: A meteorological forcing dataset for land surface- and hydrological-models, WATCH Technical Report No. 22, available at: url:http: //www.eu-watch.org/media/default.aspx/emma/org/10376311/ WATCH+Technical+Report+Number+22+The+WATCH+ forcing+data+1958-2001+A+meteorological+forcing+dataset+ for+land+surface-+and+hydrological-models.pdf, 22, 1-41, 2010 . 
Weedon, G. P., Gomes, S., Viterbo, P., Shuttleworth, J., Blyth, E., Osterle, H., Adam, J. C., Bellouin, N., Boucher, O., and Best, M.: Creation of the WATCH Forcing Data and its use to assess global and regional reference crop evaporation over land during the twentieth century, J. Hydrometeorol., 12, 823-848, doi:10.1175/2011JHM1369.1, 2011.
Yatagai, A., Kamiguchi, K., Arakawa, O., Hamada, A., Yasutomi, N., and Kitoh, A.: APHRODITE: Constructing a Long-Term Daily Gridded Precipitation Dataset for Asia Based on a Dense Network of Rain Gauges, B. Am. Meteorol. Soc., 93, 1401-1415, doi:10.1175/BAMS-D-11-00122.1, 2012. 